\title{
Accounting Comparability and Corporate Innovative Efficiency
}

\section{JUSTIN CHIRCOP}

The Management School, Lancaster University, Bailrigg, Lancaster, LA1 4YX, United Kingdom, Phone: +44 1524 - 594634, Fax: +44 1524 847321, e-mail:

j.chircop1@lancaster.ac.uk.

DANIEL W. COLLINS

Henry B. Tippie College of Business, The University of Iowa, Iowa City, IA 52242-1994, United States, Phone +1 319335 1048, Fax +1-319-335-1956, e-mail: danielcollins@uiowa.edu.

\section{LARS H. HASS}

The Management School, Lancaster University, Bailrigg, Lancaster, LA1 4YX, United Kingdom, Phone: +44 1524 - 593981, Fax: +44 1524 847321, e-mail:

1.h.hass@lancaster.ac.uk.

\section{NHAT Q. NGUYEN}

Department of Accounting, Colorado State University, Rockwell Hall 258, Fort Collins, CO 80523-1271, United States, Phone +1 970-491-0512, e-mail: nate.nguyen@ colostate.edu.

August, 2019

We gratefully acknowledge helpful comments from Mary Barth (the editor), two anonymous reviewers and workshop participants at the University of Padua, University of North Carolina at Chapel Hill, University of Iowa and the University of Lancaster. All remaining errors are our own. 


\title{
Accounting Comparability and Corporate Innovative Efficiency
}

August, 2019

\begin{abstract}
We predict that a firm's greater accounting comparability with its industry peers facilitates its learning from those peer firms' research and development (R\&D) investments, allowing that firm to have greater innovative efficiency. We estimate accounting comparability using pro-forma capitalized R\&D earnings that link lagged R\&D expenditures to future profitability employing the Almon (1965) distributed lag model. We find that greater accounting comparability leads to enhanced ability to predict future cash flows generated by $R \& D$ investments of peer firms. In the cross-section, we observe the relation between accounting comparability and innovative efficiency is stronger if peer firms exhibit higher accounting (accrual) quality and are themselves successful innovators. In sum, this study shows that a shared qualitative characteristic of accounting, namely accounting comparability, is positively associated with innovative efficiency.
\end{abstract}

JEL classifications: G12, G14, O32

Keywords: accounting comparability, innovative efficiency, product similarity, product market competition

We gratefully acknowledge helpful comments from Mary Barth (the editor), two anonymous reviewers and workshop participants at the University of Padua, University of North Carolina at Chapel Hill, University of Iowa and the University of Lancaster. 


\section{Introduction}

This study examines the association between accounting comparability of a given firm (which we refer to as the subject firm) with its industry peers and that firm's innovative investment efficiency. ${ }^{1}$ The Financial Accounting Standards Board (FASB 2010) emphasizes the importance of accounting comparability in investment decisions and argues that rational decision-making requires accounting information that is comparable to other firms' accounting measurements to properly evaluate similarities and differences in investment opportunities. Following De Franco et al. (2011), we define accounting comparability as the closeness between two firms' accounting systems that map economic events onto accounting earnings. Accounting comparability improves if firms facing similar economic events produce similar accounting earnings numbers.

To more closely link firms' performance measurements with innovative activities, we estimate accounting comparability using pro-forma capitalized research and development (R\&D) earnings that link lagged $R \& D$ expenditures to future profitability employing the Almon (1965) distributed lag model (see Sougiannis 1994; Lev and Sougiannis 1996). We reason that a firm's having greater accounting comparability with its industry peers will facilitate its learning from the $R \& D$ investment outcomes of peer firms, leading it to make better R\&D investments. We argue one way that accounting comparability improves learning is by enhancing the prediction of future operating cash flows of peer firms, particularly innovative peers. The enhanced predictive ability that arises from greater accounting comparability is particularly important given that future benefits arising from $R \& D$ investments are more uncertain than from capital investments

\footnotetext{
${ }^{1}$ We use the term "subject firm" to refer to the firm whose innovative efficiency measures are being assessed and the firm whose returns are used in computing capitalized R\&D earnings comparability. Each subject firm has unique innovative efficiency measures and a unique accounting comparability measure with its peer group. See Section 4.3 for a more complete discussion of how accounting comparability is computed. To be a subject firm, the firm must have at least one patent awarded by the U.S. Patent Office during our sample period.
} 
(Kothari et al. 2002). Therefore, we expect firms with greater accounting comparability with industry peers will generate more innovations and innovations of higher quality, which are key measures of corporate innovative efficiency.

The approach adopted in this paper differs from that in much of the prior literature that studies how qualities of a firm's own accounting information affects that firm's own investment decisions, or of the literature that investigates how accounting quality attributes of subject firms affect peer firms' investment outcomes and vice versa. ${ }^{2}$ In this paper, we study the effect of a shared qualitative characteristic of accounting, namely the comparability of accounting choices of a given firm with industry peers and how accounting comparability affects that firm's innovative efficiency, which is a key determinant of long-term success and competitiveness in a dynamic global economy. Using a large sample of U.S. firms for the period 1992 to 2006 whose R\&D investments yielded patents, we show that when a firm exhibits greater accounting comparability with industry peer firms, it generates more patents and more citations per dollar of R\&D investment after controlling for previously documented determinants of innovation. Our findings suggest accounting comparability has an economically significant relation with innovative efficiency. We estimate that a one standard deviation increase in accounting comparability yields a roughly 12 percent increase in innovative efficiency for the average firm in our sample.

We find that accounting comparability can improve innovative efficiency by enhancing the subject firm's ability to predict peer firms' future cash flows over both the short (1 year) and long (4 year) horizons. By examining peer firms' financial statements and other publicly available information (e.g. patent applications and FDA approvals) and determining how this

\footnotetext{
${ }^{2}$ For example, Biddle et al. (2009) examine how a firm's financial reporting quality affects that firm's own investment efficiency, while Badertscher et al. (2013), Beatty et al. (2013), and Shroff et al. (2013) show that a firm's accounting information affects peer firms' investment decisions and vice versa.
} 
information changes over time, a firm can ascertain which portfolio of R\&D investments leads to successful outcomes that enhance peer firms' future cash flows. Information about R\&D investments is particularly relevant for our sample of firms because annual $R \& D$ cash outflows represent roughly 60 percent of net adjusted operating cash flows for the average firm in our sample. We reason that accounting comparability facilitates a firm's understanding of how peer firms' portfolios of risky R\&D investments map onto future cash flows, which allows a subject firm to make more efficient $R \& D$ decisions.

To further corroborate our main findings, we test for cross-sectional differences in the relationship between accounting comparability and innovative efficiency. Specifically, we find the positive relationship between accounting comparability and innovative efficiency is stronger (more positive) when industry accounting quality is higher and when peer firms are themselves successful innovators. The consistency of these cross-sectional results with our main finding that accounting comparability enhances firms' innovative efficiency mitigates concerns of endogeneity and correlated omitted variables.

Our study contributes to two streams of research. First, the costs and benefits of accounting comparability remain an open issue (Schipper 2003). Although the Securities Exchange Commission (SEC 2000) and the Financial Accounting Standards Board (FASB 2010) have claimed that accounting comparability fosters more efficient allocation of capital, to date only a few empirical studies have analyzed the relationship between accounting comparability and capital allocation (De Franco et al. 2011; Brochet et al. 2013; Horton et al. 2013; and Chen et al. 2018). Our study provides additional evidence of the benefits of accounting comparability in a setting involving investments in intangible assets. Second, while it has long been recognized that creating an environment that nurtures corporate innovation is vital for an economy's 
prosperity and competitive advantage (Solow 1957), limited research exists on the role that accounting information plays in fostering innovation and enhancing the innovation process (e.g. Chang et al. 2015; and Li 2012). Our study contributes to this literature by examining how the qualitative characteristic of accounting comparability relates to a firm's ability to make better R\&D investments that lead to greater cash flows in the future.

The remainder of the paper proceeds as follows. We review related literature in Section 2 and formulate our hypotheses in Section 3. In Section 4, we present our research design, sample selection and summary statistics. In Section 5, we discuss our main results and present further analyses. Section 6 concludes.

\section{Related literature}

\subsection{Accounting comparability}

Until recently, empirical research on accounting comparability has been limited (Schipper 2003) due to the lack of a reliable empirical measure of accounting comparability. Accounting comparability measures the degree to which similar economic events are mapped into accounting numbers that are similar. De Franco et al. (2011) introduces an output-based measure of accounting comparability based on the similarity of parameters from firm-specific linear regressions of GAAP earnings on returns for a firm and its industry peers. De Franco et al. contend that accounting comparability lowers the cost of information acquisition and increases the overall quantity and quality of information available to decision makers.

A paper related to our study that uses the De Franco et al. accounting comparability measure in an investment setting is Chen et al. (2018). This paper demonstrates that acquirers make better acquisitions when target firms exhibit greater accounting comparability with the targets' industry peer firms. Our study differs from Chen et al. (2018) in four important respects. 
First, Chen et al. focus on external investments [Mergers and Acquisitions (M\&As)] that largely involve real (tangible) assets that are capitalized and appear on the financial records of the firm making the investment. Our study, on the other hand, focuses on the role that accounting comparability plays in fostering better internal $R \& D$ investments that are initially expensed under GAAP but are viewed positively as capitalized assets by the market (Lev and Sougiannis 1996). It is unclear whether the benefits of accounting comparability documented in an M\&A investment setting transfer to a setting where investments are internal and less tangible. Because the literature has emphasized the fundamental necessity of innovation for a firm's long-term prospects (e.g. Hall et al. 2001), we believe innovative investments that are intangible are an important setting in which to study the effect of accounting comparability on the ability of firms to make better investment decisions.

Second, Chen et al. (2018) compute accounting comparability based on the similarity of mappings between stock returns and reported GAAP earnings as in De Franco et al. (2011). In our study, we estimate accounting comparability using pro-forma capitalized $\mathrm{R} \& \mathrm{D}$ earnings that link lagged R\&D expenditures to future profitability employing the Almon (1965) distributed lag model (see Appendix 1 for further discussion). We use this adjusted measure of profitability because Sougiannis (1994) and Lev and Sougiannis (1996) show that the market appears to value $R \& D$ intensive firms based on their capitalizing $R \& D$ expenditures and then writing off these capitalized amounts according to the relative magnitude of the distributed lag model parameters that link lagged R\&D expenditures to future profitability. ${ }^{3}$

\footnotetext{
${ }^{3}$ Following prior literature that examines the effect of $R \& D$ on future profitability, we use R\&D expenditures to refer to R\&D cash outflows in a given period and measure this by Compustat data item XRD, which is research and development expense reported on the income statement. We acknowledge that R\&D expenditures may not equal R\&D expense because under ASC Section 730-10-25-2, firms can capitalize and then write off as amortization expense $R \& D$ expenditures for materials, equipment and facilities that have alternative future uses in other R\&D projects. We maintain that the differences between $R \& D$ expenditures and $R \& D$ expense in these instances are minimal (Bhagat and Welch 1995).
} 
A third difference between our study and Chen et al. (2018) is the firm for which accounting comparability is being computed. Chen et al. examine how accounting comparability between a target firm and its peers affects the success of M\&A investments by acquirers. Note that the firm for which accounting comparability is being computed is different from the firm that is doing the investing. Our study focuses on how accounting comparability between the firm doing the innovative investment (i.e., the subject firm) and its industry peers affects the efficiency of the R\&D investments made by the subject firm. Therefore, the firms for which accounting comparability is computed are different in the two studies.

A fourth and final key difference between our study and the Chen et al. study is that we examine a mechanism (or channel) by which accounting comparability improves the subject firm's learning about the innovative investments of industry peers. Specifically, we demonstrate that accounting comparability enhances the ability of peer earnings components (R\&D expenditures, operating cash flows, and accruals) to predict future cash flows (for both short and long horizons) of the peer firms. We show that enhanced prediction of the future cash flows of peer firms is associated with higher innovative efficiency of subject firms.

\subsection{Corporate innovation}

Innovation is a key determinant of firms' long-term success (Sougiannis 1994; Hsu 2009; and Pandit, Wasley, and Zach 2011). Hirshleifer et al. (2013) show that stock portfolios sorted on innovative efficiency earn positive risk-adjusted returns in the future. A large body of literature in economics and finance has studied the determinants of a firm's innovative success. This literature has linked innovation to financial development (Hsu et al. 2014), financing risk (Nanda and Rhodes-Kropf 2017), "hot" business cycles (Nanda and Rhodes-Kropf 2013), institutional and private ownership (Aghion et al. 2013; Ferreira et al. 2014) and industry 
competition (Aghion et al. 2004). In this study, we examine how a shared attribute of accounting systems (i.e., comparability) between subject firms and industry peer firms impacts the innovative efficiency of subject firms. Proxies for innovative efficiency are detailed in Section 4 below.

\section{Hypothesis development}

\subsection{Accounting comparability and innovative efficiency}

Peer firms' financial information can affect subject firm's innovative activities if subject firms can gain insight about investment opportunities by considering peer firms' reported financial results that can lead to enhanced ability to predict future cash flows from $R \& D$ investments with uncertain outcomes. Beatty et al. (2013) argue that firms look to peer firms' investments to reduce product market uncertainty and to identify promising investment opportunities. We reason that firms look to industry peer firms to gain insight into R\&D investment opportunities and to assess the success of those investments. We conjecture that greater accounting comparability with peer firms will facilitate the subject firm's learning process because peer firms' financial statements will be (1) more understandable, and (2) more informative for subject firm's investment decisions.

Two studies particularly relevant to ours are Sougiannis (1994) and Lev and Sougiannis (1996). Both studies use the Almon (1965) distributed lag model to estimate the lead-lag relationship between $R \& D$ expenditures and earnings. Sougiannis finds that, on average, a onedollar increase in R\&D expenditures leads to a two-dollar increase in firm profits over a sevenyear period and that investors place a high value on R\&D investments, with a one-dollar increase in $R \& D$ expenditures producing a five-dollar increase in market value. Sougiannis then separates the effect of $R \& D$ on market values into direct and indirect components. The former pertains to 
new information conveyed directly by the reported $R \& D$ expenditures, while the latter relates to the capitalized value of R\&D benefits reflected in earnings. Sougiannis (1994) demonstrates that the indirect effect is much larger than the direct effect, implying that the R\&D information conveyed by earnings numbers is more highly valued than the information conveyed by the R\&D expenditures themselves. Lev and Sougiannis (1996) extend the results in Sougiannis (1994) by deriving a measure of $R \& D$-adjusted pro-forma earnings based on the lead-lag relationship between R\&D expenditures and earnings obtained from the Almon (1965) distributed lag analysis. ${ }^{4}$ They then show these pro-forma earnings are significantly associated with firms' concurrent and subsequent market values.

We build on the work of Sougiannis (1994) and Lev and Sougiannis (1996) and modify the earnings-return mapping used in De Franco et al. (2011) to measure accounting comparability using pro-forma capitalized R\&D earnings numbers rather than GAAP earnings numbers. We do this to more explicitly tie our measurement of accounting comparability to how R\&D investments affect firms' future profitability by introducing the Almon (1965) distributed lag model. The findings in Sougiannis (1994) and Lev and Sougiannis (1996) suggest it is proforma earnings adjusted for $R \& D$ capitalization that reflect investor beliefs about the future cash flows of current and lagged $R \& D$ expenditures. We reason that subject firms learn more from peer firm R\&D expenditures, and the expected future benefits from those expenditures (as reflected in stock returns), when the mappings from stock returns onto pro-forma earnings adjusted for R\&D capitalization for peer firms are more similar to the mappings for subject firms. We predict that greater pro-forma capitalized R\&D earnings accounting comparability will

\footnotetext{
${ }^{4}$ Specifically, Lev and Sougiannis (1996) compute pro-forma earnings by capitalizing lagged R\&D expenditures and amortizing them over the periods over which $R \& D$ investments are useful.
} 
lead to better investment decisions by subject firms and, hence, in more efficient $R \& D$ investments. We formalize this prediction in the following hypothesis, stated in alternative form:

H1: Subject firms with greater (less) pro-forma capitalized R\&D accounting earnings comparability with industry peer firms exhibit more (less) innovative efficiency.

We reason that one channel by which greater accounting comparability leads to greater innovative efficiency of subject firms is through enhancing a subject firm's ability to predict cross-sectional variation in future cash flows of peer firms. We argue that peer firms' current earnings, along with their $\mathrm{R} \& \mathrm{D}$, cash flow and accrual components, are better predictors of their future cash flows when the peer firms' and subject firms employ similar accounting choices. We expect that greater accounting comparability enables a firm to better predict the effect of $R \& D$ expenditures in the current period on net operating cash inflows in future periods, especially over longer horizons. This enhanced predictability over longer horizons occurs because uncertain outcomes from R\&D investments are likely to be more predictable when those cash flows are aggregated over multiple years, which leads to the following prediction:

H2: Greater pro-forma capitalized $R \& D$ accounting earnings comparability with industry peers enhances the ability of subject firms to predict peer firms' future net operating cash flows from peer firms' current period cash flows, accruals and R\&D expenditures, especially over longer horizons when the commercial successes of current period R\&D investments are realized.

\subsection{The moderating effect of accounting quality on the relationship between accounting} comparability and innovative efficiency

Biddle and Hilary (2006) and Biddle et al. (2009) find accounting quality improves investment efficiency by reducing information asymmetry between the firm's management and outside providers of capital. In other words, high quality accounting numbers are more informative, and thus more useful, to company stakeholders. Building on these findings, we expect the quality of peer firms' accounting numbers to affect the benefits of accounting 
comparability with respect to innovative efficiency. If two firms produce low quality earnings numbers in a comparable fashion, then even though they may have comparable accounting systems, the peer firm's numbers are of limited use to the subject firm. As such, the potential benefits of learning from peer firms' investments are limited. Therefore, accounting quality and accounting comparability are compliments and jointly determine the learning that occurs from peer firms' financial statements. We formalize this prediction in the following hypothesis:

H3: The relationship between pro-forma capitalized R\&D accounting earnings comparability and innovative efficiency is stronger if peer firms have higher accounting (i.e., accrual) quality.

\subsection{Innovative versus non-innovative peers}

Hypothesis 1 makes the implicit assumption that learning from peer firms is a function of average accounting comparability of the subject firm with all industry peer firms regardless of whether or not peer firms are themselves engaged in innovative activity. However, this assumption may not be true. Specifically, it is likely that subject firms will learn more from innovatively successful peer firms than from innovatively unsuccessful peer firms, or from peer firms that do not engage in innovative activity. ${ }^{5}$ This reasoning leads us to predict the association between a firm's accounting comparability and innovative efficiency is stronger when peer firms are themselves successful innovators. We formalize this prediction in the following hypothesis:

H4: The relationship between pro-forma capitalized R\&D accounting earnings comparability and innovative efficiency of subject firms is stronger (weaker) if peer firms are innovators (non-innovators).

\footnotetext{
${ }^{5} \mathrm{We}$ are unable to distinguish between peer firms that engage in innovative activities but are unsuccessful in obtaining a patent and peer firms that do not engage in innovative activities. For this study, both kinds of firms are considered non-innovators.
} 


\section{Research design, data sources and variable measurements}

\subsection{Data sources and sample selection}

Our sample consists of firm-years in the intersection of Compustat, CRSP, Thomson Reuters Institutional (13f) Holdings data and the National Bureau of Economic Research (NBER) patent database. We obtain the required accounting data from Compustat, market data from CRSP, institutional ownership data from Thomson Reuters and patent and citation data from the NBER patent database that contains data for the years 1976 to $2006 .{ }^{6}$ With the exception of hypothesis 4 , peer firms used in calculating accounting comparability consist of all firms at the intersection of Compustat and CRSP that are in the subject firm's two-digit SIC code industry. Thus, the comparability score is computed over a mixture of peer firms whose R\&D expenditures led to successful outcomes as indicated by patents (innovative firms) and those firms whose R\&D expenditures did not lead to one or more patents (non-innovative firms).

To test hypothesis 4 , we split peer firms that compose the intersection of Compustat and CRSP into two groups. The Innovative Peer Sample consists of those peer firms granted one or more patents and featured in the NBER patent database. The Non-Innovative Peer Sample consists of those firms at the intersection of Compustat and CRSP not featured in the NBER patent database. Hence, these firms have not received any patents. Thus, for each observation in our subject firm sample, we can calculate two distinct measures for accounting comparability: 1) accounting comparability using only innovative peers, and 2) accounting comparability using only non-innovative peers. We test hypothesis 4 by including both comparability scores in the same regression.

\footnotetext{
${ }^{6}$ This database is publicly available at https://sites.google.com/site/patentdataproject/Home.
} 
Following Hirshleifer et al. (2013), we exclude from our sample financial firms, i.e. firms that have two-digit SIC codes from 61 to 69 , holding companies, group companies, limited partnerships and American Depository Receipts (ADRs). We also drop observations where the firm has a negative book value of equity. Our final sample consists of 9,772 firm-year observations for 1,861 subject firms for the period 1992 to 2006, the last year for which we have patent data. As discussed in the following sections, for parts of our analyses we lose observations due to limited data availability.

\subsection{Measures of innovative efficiency}

We calculate two measures of innovative efficiency based on the patent and citation data in the NBER patent database. This database, originally developed by Hall et al. (2001) and used in several other studies (e.g. Aghion et al. 2013; Atanassov 2013; He and Tian 2013; Hirshleifer et al. 2013; Tian and Wang 2014; Fang et al. 2014; and Seru 2014), provides detailed information for patents granted by the US Patent and Trademark Office (USPTO) between January 1976 and December 2006. Specifically, this database has patent assignee names and Compustat-matched identifiers, number of patent citations and identifiers of the patents making such citations, application and grant dates among other details.

We calculate two measures of innovative efficiency: the first is based on the number of patents that are granted (IE_PATENTS), while the second is based on citations (IE_CITATIONS) to those patents. Variable IE_PATENTS is calculated as the sum of all patents granted in a particular year $t$ scaled by $\mathrm{R} \& \mathrm{D}$ capital, which is the sum of $\mathrm{R} \& \mathrm{D}$ expenditures over a five-year period assuming a depreciation rate of 20 percent as in Chan et al. (2001), Lev et al. (2005), and 
Hirshleifer et al. (2013). ${ }^{7}$ Given it takes on average roughly two years for USPTO to grant a patent application (Hall et al. 2001), our five-year period ends two years prior to grant date $t$-2:

$$
I E_{-} P A T E N T S=\frac{\operatorname{SUMPATENTS}_{i t}}{\left(R \& D_{i t-2}+0.8 * R \& D_{i t-3}+0.6 * R \& D_{i t-4}+0.4 * R \& D_{i t-5}+0.2 * R \& D_{i t-6}\right)}
$$

where SUMPATENTS $S_{i t}$ is the sum of patents assigned to firm $i$ granted in year $t$ while $R \& D_{i t-2}$ refers to research and development expenditures for fiscal year ending at $t-2$ and so on. The use of R\&D capital computed over a five-year period assumes $\mathrm{R} \& \mathrm{D}$ expenditures over the period $t-2$ to $t-6$ contribute towards a successful patent application. Like Hall et al. (2001) and Hirshleifer et al. (2013), we set missing values for R\&D expenditure to zero.

As our first measure of innovative efficiency does not reflect innovation quality, we construct another innovative efficiency metric based on citations. Specifically, the number of patents used in constructing IE_PATENTS reflects the quantity but not the quality of patents granted. Conversely, the number of citations to a patent indicates the quality of that patent as perceived by other innovative firms. IE_CITATIONS is calculated as the sum of adjusted citations scaled by $R \& D$ capital over the five years after grant date for all patents granted in year $t^{8}$

To calculate IE_CITATIONS, we first determine the sum of total citations for each patent and scale it by the mean number of citations in each grant year per industry for each year in the sample. This adjustment controls for any bias in citations based on industry, grant year or citation year (Gu 2005; and Pandit et al. 2011). We sum the adjusted citations for each patent for

\footnotetext{
${ }^{7}$ Similar results are obtained if, instead of calculating the sum of patents for firm $i$ for grant year $t$, the sum of the patents is calculated for the application year.

${ }^{8}$ Adjusted citations is the sum of total citations for each patent scaled by the mean number of citations for each grant year per industry (Hirshleifer et al. 2011). Ideally, we would like to consider all citations over the life of the patent because patents take time to be cited (Trajtenberg 1990; Harhoff et al. 1999; Hall et al. 2005; and Hirshleifer et al. 2013). Because considering the number of citations over the entire life of the patent is not feasible, we consider citations for the five years following the patent grant date (Hirshleifer et al. 2013).
} 
the five years after grant date and then sum the adjusted citations for each firm based on the patent grant year $\left(S U M \_A D J \_C I T\right)$. Finally, we scale the sum of the adjusted citations for each firm by R\&D capital. Following Hirshleifer et al. (2013), R\&D capital is calculated as the weighted sum of $\mathrm{R} \& \mathrm{D}$ expenditures for the period $t-3$ to $t-7$ where the weighting assumes a depreciation rate of 20 percent. $^{9}$ Any missing values for R\&D expenditure are set to zero.

$$
I E_{-} C I T A T I O N S=\frac{S U M_{-} A D J_{-} C I T_{i t}}{\left(R \& D_{i t-3}+0.8 * R \& D_{i t-4}+0.6 * R \& D_{i t-5}+0.4 * R \& D_{i t-6}+0.2 * R \& D_{i t-7}\right)}
$$

\subsection{Measure of accounting comparability}

Like De Franco et al. (2011), we define accounting comparability as the closeness or similarity between two firms' accounting systems. This closeness or similarity is determined by how economic events during a period are mapped onto accounting numbers. Consistent with De Franco et al., we choose stock returns as a summary measure for the underlying economic events of a company.

Prior research (Sougiannis 1994; Lev and Sougiannis 1996; and Chan et al. 2001) shows a strong association between earnings adjusted for $R \& D$ capitalization and stock returns indicating that $R \& D$ capitalization is value-relevant for investors. Therefore, we use earnings adjusted for R\&D capitalization as our summary measure of the accounting choices made by firms engaging in R\&D activity. Specifically, following Sougiannis (1994) and Lev and Sougiannis (1996), we adjust reported earnings by adding back after-tax current period R\&D expenditures and subtracting after-tax amortization of previous years' capitalized R\&D amounts to net income before extraordinary items. ${ }^{10} \mathrm{We}$ detail the approach adopted to calculate pro-

\footnotetext{
${ }^{9}$ Starting at $t$ - 3 considers the two-year period it typically takes USPTO to grant a patent application and another year to account for a patent to start being cited.

${ }^{10}$ Specifically, adjusted earnings is calculated as net income before extraordinary items in period $t+[(\mathrm{R} \& \mathrm{D}$ expenditures in period $t-\mathrm{R} \& \mathrm{D}$ amortization in period $t) \times(1-$ tax rate) $]$. The amount of $\mathrm{R} \& \mathrm{D}$ amortization of
} 
forma earnings adjusted for R\&D capitalization in Appendix 1.

Given the evidence in the studies cited above, we amend the De Franco et al. procedure for calculating accounting comparability and assess whether two firms produce similar accounting numbers given the same set of economic events by estimating how stock returns map onto adjusted pro-forma capitalized R\&D earnings rather than onto GAAP earnings. This adjustment to the De Franco et al. measure aligns our measure of accounting comparability with what firms spend on R\&D, with how these expenditures are linked to future earnings through the Almon (1965) distributed lag model, and with how the market appears to value these R\&D expenditures as investments.

We estimate the mapping from returns onto pro-forma earnings for an individual firm $i$ using the following time-series regression estimated over the 24 quarters of data prior to the fiscal year-end in which the patent was granted: ${ }^{11}$

$$
\text { Adjusted Earnings } s_{i t}=\alpha_{i}+\beta_{i} \text { Return }_{i t}+\varepsilon_{i t}
$$

where Adjusted Earnings is quarterly net income before extraordinary items adjusted for R\&D capitalization scaled by the beginning of period market value of equity and Return is the stock market return during the quarter calculated as the exponential of the sum of monthly returns during the quarter minus one. We use 24 quarters to ensure the period over which accounting comparability is computed aligns with the period over which innovative efficiency is calculated. ${ }^{12}$ The estimated intercept $\left(\hat{\alpha}_{i}\right)$ and slope coefficient $\left(\hat{\beta}_{i}\right)$ are firm-specific accounting system parameters that map economic events (returns) onto adjusted earnings for subject firm $i$.

previous years' R\&D expenditures is determined by the lag structure estimated from the Almon (1965) distributed lag model.

${ }^{11}$ For each observation, we require data for at least 14 of the 24 quarters.

${ }^{12}$ In line with Hirshleifer et al. (2013), when computing IE_PATENTS, we assume that R\&D expenditure over the 6 years (24 quarters) prior to the patent grant year contributes to the successful completion of the R\&D project. 
The accounting function for peer firm $j$ from the same two-digit SIC industry as firm $i$ is proxied by $\hat{\alpha}_{j}$ and $\hat{\beta}_{j}$, where these parameters are estimated using the adjusted earnings and returns for firm $j$. When these two accounting parameter estimates are applied to subject firm $i$ 's economic events (i.e., Return), the resulting numbers in the equations below are the predicted adjusted earnings (i.e., the expected accounting outcomes) of firms $i$ and $j$, respectively, for the same economic events (i.e., subject firm i's returns). Note the superscript on expected adjusted earnings in the equations below denotes which firm's returns are used (i.e., the subject firm), while the subscript indicates which firm's accounting system parameters are used.

$$
\begin{aligned}
& E\left(\text { Adjusted Earnings }_{i t}^{i}\right)=\hat{\alpha}_{i}+\hat{\beta}_{i} \text { Return }_{i t} \\
& E\left(\text { Adjusted Earnings }_{j t}^{i}\right)=\hat{\alpha}_{j}+\hat{\beta}_{j} \text { Return }_{i t}
\end{aligned}
$$

where $E$ (Adjusted Earnings $s_{i t}^{i}$ ) is the predicted earnings of subject firm $i$ given firm $i$ 's function and firm $i$ 's returns in period $t$; and $E$ (Adjusted Earnings $s_{j t}^{i}$ ) is the predicted earnings of peer firm $j$ given firm $j$ 's function and subject firm $i$ 's return in period $t$. Comparability between subject firm $i$ and peer firm $j$ accounting systems (CompAcct) is defined as follows:

$$
\text { CompAcct }_{i j t}=\frac{1}{\tau} \sum_{t-\tau}^{t} \mid E\left(\text { Adjusted Earnings }_{i t}^{i}\right)-E\left(\text { Adjusted Earnings }_{j t}^{i}\right) \mid
$$

where $\tau$ is the number of quarters in the estimation period. The more comparable the two firms' accounting systems, the smaller the difference between the two expected adjusted earnings amounts in Eq. (6). To facilitate interpretation, we multiply the average absolute difference in Eq. (6) by minus one so that greater (less negative) numbers indicate greater accounting comparability between firms $i$ and $j$. We estimate the CompAcct score for each subject firm $i$, peer firm $j$ combination in the same two-digit SIC industry as the subject firm, where the subject firm is the firm whose patent and citation counts are being evaluated. We then compute the average of CompAcct for each subject firm with all other firms in the same two-digit industry, 
which we call $C O M P .{ }^{13} \operatorname{COMP}_{i t}$ is the subject firm $i$ firm-specific accounting comparability measure for period $t$ used in testing our hypotheses.

It is important to note that the subject firm's accounting comparability measure we use in our tests represents an average across the number of subject firm - peer firm pairs within the subject firm's two-digit SIC code industry. This averaging process minimizes noise in the individual firm pairwise CompAcct $_{i j t}$ scores, which allows the shared elements of accounting choices of subject firms and peer firms to be more visible in our measurement of accounting comparability. We reason that it is the variation in elements of firms' accounting choices that are shared with peer firms as reflected in this accounting comparability measure that impacts innovative efficiency outcomes of subject firms.

\subsection{Empirical model for examining the effects of accounting comparability on innovation outcomes.}

To test hypothesis 1 , we estimate the following cross-sectional regression model:

$$
\begin{aligned}
& I E_{i t}=\beta_{0}+\beta_{1} \text { COMP }_{i t}+\beta_{2} \text { SIZE }_{i t}+\beta_{3} M T B_{i t}+\beta_{4} L E V_{i t}+\beta_{5} \text { CAPINT }_{i t}+\beta_{6} R D S_{i t}+ \\
& \beta_{7} \text { ROA }_{i t}+\beta_{8} I_{i t}+\beta_{9} S T D A Q_{i t}+\beta_{10} \text { TOBINQ } \\
& \beta_{13}+\beta_{11} \text { SYNC }_{i t}+\beta_{12} \text { CORR }_{i t}+ \\
& \beta_{i t}+\text { Industry Fixed Effects } \\
& +\varepsilon_{i t}
\end{aligned}
$$

where $I E_{i t}$ refers to the two measures of innovative efficiency for subject firm $i$ in year $t$ and is either IE_PATENTS or IE_CITATIONS. COMP is accounting comparability. SIZE, MTB, LEV, CAPINT, RDS, ROA, IO, STDAQ, TOBINQ, SYNC, CORR, OCFVOL and Industry Fixed Effects are the vector of control variables for the subject firms.

We control for SIZE, calculated as the logarithmic transformation of total assets, to proxy for financial constraints on firms' ability to engage in greater innovation. Livdan et al. (2009) show that smaller firms are generally more financially constrained than larger firms because

\footnotetext{
${ }^{13}$ We obtain qualitatively similar results if we run our analyses using COMP computed as the median instead of as the average CompAcct for each subject firm.
} 
internal funds are more limited but desired investments are higher. Market-to-book ratio $(M T B)$, computed as market value of equity scaled by the book value of equity, controls for differences in firms' growth prospects. We control for leverage ( $L E V)$ because debt affects a firm's R\&D and patenting activity (Bhagat and Welch 1995; Aghion et al. 2004; and Atanassov et al. 2007).

We include CAPINT, which is the logarithmic transformation of total assets scaled by number of employees, to control for the potential link between capital intensity and innovative efficiency (Aghion et al. 2013). We also control for R\&D intensity (RDS), calculated as the log of $\mathrm{R} \& \mathrm{D}$ expenses scaled by lagged total assets, and performance $(R O A)$, calculated as income before extraordinary items scaled by lagged total assets. $R D S$ controls for the association between the level of R\&D spending and innovative efficiency, while $R O A$ controls for the potential link between performance and innovative efficiency (Hirshleifer et al. 2013). We include $I O$, which denotes the fraction of firm shares owned by institutional investors, to control for the effect of investor sophistication on innovative efficiency (Aghion et al. 2013). Given Biddle and Hilary (2006) and Biddle et al. (2009) show that higher-quality financial reporting improves capital investment efficiency by limiting deviations from optimal investment policy, we control for accounting quality $(S T D A Q) .{ }^{14}$ We measure accounting quality as the standard deviation of the residuals, obtained from running an OLS regression on the same 24 quarters used in calculating accounting comparability. The dependent variable in this regression is working capital accruals and the independent variables are the explanatory variables in the Jones (1991) and the Dechow and Dichev (2002) models. ${ }^{15}$ A larger standard deviation of the regression residuals indicates lower accounting quality. To facilitate the interpretation of the

\footnotetext{
${ }^{14}$ Later, in section 5.3, we explore how accounting quality conditions the effects of COMP on investment efficiency. 15 We follow McNichols (2002) and estimate accounting quality using the following model: $\Delta W C_{t}=b_{0}+$ $b_{1} C F O_{t-1}+b_{2} C F O_{t}+b_{3} C F O_{t+1}+b_{4} \Delta$ Sales $_{t}+b_{5} P P E_{t}+\varepsilon_{t}$ where $\triangle W C$ is changes in working capital, $C F O$ is cash from operations, $\triangle$ Sales is changes in sales and $P P E$ is gross property, plant and equipment. All variables are deflated by average total assets.
} 
coefficient on this variable, we multiply this measure by minus one so that higher (less negative) numbers indicate higher accounting quality of the firm. Further, we standardize this variable so that it has a mean of 0 and a standard deviation of 1 .

To help ensure that our measure of accounting comparability captures similarity in accounting choices rather than similarity in the firm's investment opportunity set or underlying economics, we include three additional controls - TOBINQ, SYNC, and CORR. TOBINQ, calculated as the sum of the market value of equity and debt scaled by total assets, controls for the firm's investment opportunity set. $S Y N C$ is calculated as the adjusted R-squared from a market model OLS regression, while CORR is calculated as the average correlation of the firms' monthly returns with the respective returns for firms with the same two-digit SIC code. SYNC and CORR control for similarity in the underlying economics of the firm with those of peer firms. These three measures are calculated over the same 24 quarters used in calculating COMP.

To ensure that our measure of accounting comparability is not merely capturing idiosyncratic firm risk, we also include an accounting measure of firm risk, operating cash flow volatility $(O C F V O L) .{ }^{16} O C F V O L$ is measured as the operating cash flow coefficient of variation over the 24 quarters used in calculating COMP and ranked into scaled deciles. ${ }^{17}$ The higher $O C F V O L$, the higher the operating cash flow volatility and thus the higher the firm risk. Finally, we control for industry-fixed effects to control for heterogeneous patenting activity across industries and winsorize all continuous variables at the 5 percent level at both ends to control for possible outliers. ${ }^{18}$ Appendix 2 provides details of the variables used in the empirical analyses.

\footnotetext{
${ }^{16}$ SYNC indirectly controls for idiosyncratic risk, as it is calculated as the adjusted R-squared of a market model OLS regression. Idiosyncratic risk is measured as the variance of the market model residuals.

${ }^{17}$ Scaled deciles are the deciles divided by nine so that $O C F V O L$ takes a value between 0 and 1.

${ }^{18}$ We obtain similar results when we control for year fixed effects and when we winsorize at the 1 percent level.
} 


\subsection{Empirical model for examining the effects of accounting comparability on the predictive ability of peer firm earnings components with respect to peer firm future cash flows}

To test hypothesis 2 that greater accounting comparability enhances the ability of subject firms to predict cross-sectional variation in future cash flows of peer firms from their current period cash flows, accruals and R\&D expenditures, we use the following specification:

$C F_{j t+1}^{*}\left(C F_{j t+1 \text { to } t+4}^{*}\right)=\beta_{0}+\beta_{1} C F_{j t}+\beta_{2} R \& D_{j t}+\beta_{3} A C C_{j t}+\beta_{4} C F_{j t} * C O M P^{`}{ }_{i t}+$ $\beta_{5} R \& D_{j t} * \operatorname{COMP}^{\prime}{ }_{i t}+\beta_{6} A C_{j t} * \operatorname{COMP}_{i t}{ }_{i t}+\beta_{7} \operatorname{COMP}^{\prime}{ }_{i t}+$ Industry Fixed Effects $+\varepsilon_{j t}$

where $j$ refers to peer firms operating in subject firm $i$ 's two-digit SIC industry code and $t$ refers to the fiscal year. To increase the power of this test, we transform our measure of accounting comparability into an indicator variable, $\operatorname{COMP}^{`}{ }_{i t}$, which takes the value of 1 for observations with accounting comparability in the top quartile of our sample. Because we seek to capture the increased ability of subject firms to predict peer firms' future cash flows using their current earnings components, all variables except for $\operatorname{COMP}^{`}{ }_{i t}$ are for the peer firms (denoted with a $j$ subscript) while $\operatorname{COMP}^{`}{ }_{i t}$ captures accounting comparability between the subject firm $i$ and the peer firms from that subject firm's two-digit SIC industry as outlined in Section 4.3.

This specification is a modified version of the model in Barth et al. (2001) used to evaluate the predictive ability of the cash flow and accrual components of earnings with respect to future operating cash flows. The interaction terms capture the increase in the ability of a subject firm to predict peer firms' future cash flows from peer firms' current earnings components when accounting comparability between the subject firm and its industry peer firms is high (top quartile). Furthermore, given our interest in whether R\&D expenditures in the current period predict future operating cash flows and because we isolate $R \& D$ expenditures as a separate component of earnings on the right hand side of Eq. (8), we use net operating cash flows

before deducting R\&D expenditures as the dependent variable in Eq. (8), which we denote 
$C F^{*}{ }_{j+1}$ or $C F^{*}{ }_{j+1}$ to $t+4$. We make this adjustment for two reasons. First, R\&D expenditures are highly serially correlated (the median serial correlation between $R \& D_{j t}$ and $R \& D_{j t+1}$ is 0.447 ). Second, R\&D expenditures account for a significant proportion of net operating cash flows (median absolute value of $\mathrm{R} \& \mathrm{D}$ expenditures scaled by operating cash flows is 54.2 percent). Thus, without this adjustment there would be a spurious significant positive association between $R \& D_{j t}$ and $C F_{j t+1}$ simply because of the high serial correlation in R\&D expenditures, which is a major component of firms' net operating cash flows.

Because we are interested in understanding how accounting comparability (COMP) affects the ability of the subject firm to predict peer firms' future cash flows using peer firms' current earnings components, we employ two alternative measures of operating cash flows as our dependent variable: adjusted operating cash flows one year ahead $\left(C F_{j t+1}^{*}\right)$ and aggregated adjusted operating cash flows over four years ahead $\left(C F^{*}{ }_{j t+1}\right.$ to $\left.t+4\right)$. We use this aggregated cash flow measure because the impact of current period expenditures for $R \& D$ on future net operating cash flows can take several years to materialize.

Regarding explanatory variables, in addition to the current period operating cash flows $\left(C F_{j t}\right)$ and accruals $\left(A C C_{j t}\right)$, we include as a separate explanatory variable the $\mathrm{R} \& \mathrm{D}$ expenditures in the current period $\left(R \& D_{j t}\right)$. Because current period $\mathrm{R} \& \mathrm{D}$ expenditures are part of current period $C F_{j t}$ and $A C C_{j t}{ }^{19}$ the coefficients on these latter two variables represent the predictive abilities of operating cash flows and accruals that are incremental to the effect of $R \& D_{j t}$ on future operating cash flows. Thus, $\beta_{1}$ captures the predictive ability of peer firms' operating cash flows except for $\mathrm{R} \& \mathrm{D}$ cash outflows in the current period; $\beta_{2}$ captures the predictive ability of peer

\footnotetext{
${ }^{19}$ Because most $\mathrm{R} \& \mathrm{D}$ expenditures are expensed as incurred, these expenditures are a significant portion of the current period net operating cash flows. Some portion of current period $\mathrm{R} \& \mathrm{D}$ expenditures may also be part of $A C C$ because U.S. GAAP allows firms to capitalize and then later write off as expense R\&D expenditures for materials, equipment and facilities that have alternative future uses in other R\&D projects or otherwise (see ASC Section 73010-25-2).
} 
firms' current R\&D expenditures on future operating cash flows, and $\beta_{3}$ captures the predictive ability of peer firms' net aggregate accruals except for that portion of accruals that is part of current period $R \& D$ expenditures.

Prior research (Dechow 1994 and Barth et al. 2001) shows that both current period operating cash flows and current period accruals are positively related to one-period ahead operating cash flows. Hence, we expect $\beta_{1}$ and $\beta_{3}$ to be positive for both $C F_{j t+1}^{*}$ and $C F_{j t+1}^{*}$ to t+4. We expect current period $\mathrm{R} \& \mathrm{D}$ expenditures $\left(R \& D_{j t}\right)$ to be positively associated with both cash flows one year ahead $\left(C F^{*}{ }_{j t+1}\right)$ and cash flows aggregated over four years ahead $\left(C F^{*}{ }_{j t+1}\right.$ and $C F^{*}{ }_{j t+1 \text { to } t+4)}$ as period $t \mathrm{R} \& \mathrm{D}$ expenditure produces commercially viable products that generate positive future cash flows. Thus, we expect $\beta_{2}$ in Eq. (8) to be positive.

Consistent with our predictions in hypothesis 2, we expect that greater accounting comparability with peer firms enhances the ability of subject firms to predict peer firms' crosssectional variation in future cash flows using peer firms' current period earnings components (i.e., R\&D expenditures, operating cash flows, and accruals). We also expect accounting comparability to enhance subject firm's ability to predict peer firms' future cash flows using peer firms' current accruals because U.S. GAAP allows firms to capitalize and later expense R\&D costs incurred for materials, equipment and facilities if these items have alternative future uses in other R\&D projects. ${ }^{20}$ In addition, firms that produce commercial software are permitted to capitalize and later write off $R \& D$ costs once the project reaches a commercially viable state. Based on our previous discussion, we predict the coefficients on the interaction terms $\left(\beta_{5}, \beta_{6}\right.$, and $\beta_{7}$ ) will be significantly positive. Moreover, we expect $\operatorname{COMP}^{`}$ to have a greater effect on the relation between current period $\mathrm{R} \& \mathrm{D}$ expenditures $\left(R \& D_{j t}\right)$ and future cash flows aggregated

\footnotetext{
${ }^{20}$ FASB ASC Section 730-10-25-2, Elements of Costs to be Identified with Research and Development Activities.
} 
over longer horizons $\left(C F^{*}{ }_{j t+1}\right.$ to $\left.t+4\right)$ as it takes time for future cash flow benefits of R\&D investments to be realized. Hence, we expect $\beta_{5}$ on $R \& D_{j t} * C O M P_{i t}^{\prime}$ to be more strongly positively related to future cash flows aggregated over longer horizons than over shorter horizons.

To show that increased cash flow predictive ability acts as a mediating variable in the relationship between accounting comparability and innovative efficiency, we need to establish that increased predictive ability is associated with higher innovative efficiency. To examine whether accounting comparability improves innovative efficiency by enhancing the predictive ability of peer firms' earnings components with respect to their future cash flows, we capture predictive ability by computing a measure of cash flow forecast accuracy, $C F \_F A$, for each subject firm $i$. We compute the forecast accuracy for predicting both one year ahead and aggregate four year ahead cash flows for peer firms in subject firm $i$ 's two-digit SIC code industry. The first measure captures the firm's forecast accuracy in predicting peer firms' adjusted cash flows for one period ahead, and the second measure captures the firm's forecast accuracy in predicting peer firms' aggregate adjusted cash flows for the period $t+1$ to $t+4$. For forecast accuracy in predicting peer firms' adjusted cash flows for one period ahead, we use the residuals from Eq. (8) when $C F^{*}{ }_{j t+1}$ is the dependent variable. For forecast accuracy in predicting peer firms' aggregate adjusted cash flows for the period $t+1$ to $t+4$, we use the residuals from Eq. (8) when $C F^{*}{ }_{j+1}$ to $t+4$ is the dependent variable. In both cases, forecast accuracy is measured as the absolute value of the median residual scaled by the predicted cash flow multiplied by minus one, so that a more positive measure of forecast accuracy indicates greater predictive ability. 
To formally test whether the increased predictive ability of future cash flows of peer firms enhances the innovative efficiency of subject firms, we include $C F \_F A$ in Eq. (7). In line with our previous discussion, we expect forecast accuracy to be positively related to innovative efficiency.

\subsection{Distributional statistics and correlations}

Table 1, Panel A shows the distribution of the 9,772 subject firm observations over our sample period. The year with largest (smallest) number of observations is 2005 (1992) with 8.68 (4.54) percent of the total number of observations in our sample. Panel B of Table 1 presents the distribution of sample observations by industry. Our sample of subject firms receiving patents spans thirty-four industries, strengthening the external validity of our findings. The industries most represented in our sample are the Chemicals and Electronics industries, accounting for 18.51 and 18.41 percent of the total number of observations in our study, respectively.

$$
<<\text { Insert Table } 1 \text { around here }>
$$

Table 2, Panel A shows the distributional statistics for the variables used in Eq. (7). Our measures of innovative efficiency have a similar distribution with IE_PATENTS having a mean (median) of $0.162(0.067)$ and IE_CITATIONS a mean (median) of $0.157(0.052)$. Standard deviations for the two variables are also similar (0.247 for IE_PATENTS and 0.263 for IE_CITATIONS). The distributions of these variables are comparable to those documented in Hirshleifer et al. (2013). Panel B shows the Pearson correlation matrix for the variables of interest. Consistent with our expectations, the correlation coefficients for IE_PATENTS and IE_CITATIONS exhibit a positive correlation of 9.4 and 2.4 percent, respectively, with accounting comparability, COMP. These univariate results, which are significant at the 5 percent level, suggest higher pro-forma accounting comparability based on capitalized R\&D is associated with higher innovative efficiency. 
The correlation results show that our measures of innovative efficiency are significantly negatively correlated with SIZE, MTB, CAPINT, RDS, IO, SYNC and CORR. These univariate results suggest larger firms with higher growth and higher R\&D expenditures are less efficient innovators. Further, in line with our expectations, $S T D A Q$ and $T O B I N Q$ are positively correlated with our innovative efficiency metrics, indicating higher accounting quality and better investment opportunities are related to higher innovative efficiency. Interestingly, $R O A$ is significantly positively correlated with $I E \_P A T E N T S$ but significantly negatively correlated with IE_CITATIONS. These results indicate that while better-performing firms tend to have higher patents per dollar invested in R\&D activities, these patents tend to be of lower quality and thus cited less frequently. We find no significant correlation between our measure of firm risk, OCFVOL, and our measures of innovation efficiency.

\section{$<<$ Insert Table 2 around here >>}

\section{Empirical results}

\subsection{Test results for hypothesis 1 -accounting comparability and innovative efficiency}

In Table 3, we find a statistically significant positive association between accounting comparability, COMP, and both innovative efficiency measures. Thus, consistent with hypothesis 1 , these results suggest that higher accounting comparability is associated with higher innovative efficiency after controlling for other determinants of innovative efficiency. Our results indicate that a one-standard deviation increase in accounting comparability, COMP, increases $I E \_P A T E N T S$ by 0.019 , which is equivalent to an increase of 12 percent at the mean level of IE_PATENTS. ${ }^{21}$

\footnotetext{
${ }^{21}$ Multiplying the standard deviation of accounting comparability, COMP, (1.137) by the coefficient on COMP when $I E \_P A T E N T S$ is the dependent variable (0.017) suggests that a one-standard deviation increase in accounting comparability increases IE_PATENTS by 0.019 . This change in IE_PATENTS is equivalent to an increase of 12 percent in the sample mean (0.162). The increase of 12 percent in investment efficiency can be viewed as either an
} 


\section{$<<$ Insert Table 3 around here >>}

With respect to the control variables, SIZE is negatively associated with our innovative efficiency metrics suggesting that smaller firms have higher innovative efficiency, perhaps because they are more financially constrained and more cautious in their investment decisions relative to larger firms. Interestingly, we find a negative association between institutional ownership (IO) and innovative efficiency, which suggests that while institutional ownership gives rise to increased innovation (Aghion et al. 2013), it is associated with a decrease in innovative efficiency, i.e., a decrease in the number of patents (citations) for every dollar invested. In line with evidence in Biddle and Hilary (2006) and Biddle et al. (2009) that higher accounting quality improves capital investment efficiency, we find a significant positive association between $S T D A Q$ and our innovative efficiency measures. This finding suggests that the higher the accounting quality the more efficient firms are in their research and development investment. ${ }^{22}$ Finally, for both IE_PATENTS and IE_CITATIONS, we find a statistically significant positive association with $T O B I N Q$, suggesting that firms with higher investment opportunities generate more patents and receive more citations for each dollar spent on research and development activities.

5.2 Test results for hypothesis 2 - role of accounting comparability in enhancing the predictive ability of peer firms' earnings components with respect to peer firms' future cash flows

Table 4 reports the results on how accounting comparability enhances the ability of subject firms to predict peer firms' future cash flows using peer firms' current period earnings

increase of 12 percent in the number of patents developed (keeping R\&D expenditures constant) or a decrease of 12 percent in R\&D expenditures (keeping patents granted constant). The former view suggests a one-standard deviation increase in accounting comparability increases patents granted for the average sampled firm from 25 to 28 patents per year. The latter view suggests a one-standard deviation increase in accounting comparability reduces R\&D expenditures for the average sampled firm from $\$ 155$ million to $\$ 136$ million.

${ }^{22}$ This result is in line with $\mathrm{H} 3$, where we propose that the effect of accounting comparability on innovative efficiency is stronger when peer firms have higher accounting quality. 
components. As discussed in Section 4.5, to better understand how accounting comparability enhances the ability of subject firms to predict peer firms' future cash flows from peer firms' current period earnings components, we include in our model $R \& D_{j t}$, which is current period R\&D expenditures scaled by average total assets. If our conjecture that accounting comparability improves innovative efficiency by enhancing the ability of subject firms to predict peer firms' future cash flows from those firms' $R \& D$ expenditures is correct, then we expect the coefficient $\beta_{5}$ on the $R \& D_{j t} * C O M P^{`}{ }_{i t}$ interaction term to be significantly positive. Similarly, we expect accruals to be more strongly positively associated with future operating cash flows when accounting comparability is higher because U.S. GAAP allows firms to capitalize and then later amortize R\&D expenditures for materials, equipment and facilities that have alternative future uses in other R\&D projects. ${ }^{23}$ Thus, we expect $\beta_{6}$ on the $A C C_{j t} * C O M P^{`}{ }_{i t}$ interaction term to be positive.

We run Eq. (8) for each peer firm - subject firm combination. The future cash flows and current period earnings components are for the peer firms in each subject firm's two-digit SIC code industry, while $\operatorname{COMP}^{`}{ }_{i t}$ captures accounting comparability averaged over subject firm $i$ and peer firms $j$. Note that the same firm will be a peer firm for multiple subject firms if there is more than one subject firm in that industry. As peer firms enter our analysis multiple times, we double cluster standard errors by peer firm and year to ensure that including the same peer firm multiple times does not bias our results.

The results reported in Panel A of Table 4 indicate that, when accounting comparability is high, current period $R \& D$ expenditures are better predictors of future period cash flows. The $\beta_{5}$ coefficient on the $R \& D_{j t} * C O M P^{\prime}{ }_{i t}$ interaction term is 0.126 when predicting one-year ahead

\footnotetext{
${ }^{23}$ See ASC Section 730-10-25-2.
} 
operating cash flows and 0.620 when predicting aggregated cash flows over four years in the future. Both coefficients are significant at the 1 percent level. A test for differences in coefficients suggests the difference between these two coefficients is statistically significant indicating that it takes time for $\mathrm{R} \& \mathrm{D}$ investments to lead to commercially viable products that generate positive cash flows. The $\beta_{6}$ coefficient on the $A C C_{j t} * C O M P_{i t}{ }_{i t}$ is positive for both oneperiod ahead and aggregated four-period ahead cash flows. This result is consistent with higher accounting comparability increasing the ability of a firm to predict peer firms' future cash flows from their current period accruals.

Consistent with the findings in Dechow (1994) and Barth et al. (2001), we find a positive association between current period cash flows and future operating cash flows (adjusted for R\&D cash outflows) over both short (one-period ahead) and long (aggregated four-period ahead) horizons. More notably, the coefficient estimates and t-statistics of the interaction between $R \& D$ and $\mathrm{COMP}^{\prime}$ it are the strongest among the three interactions for both horizons. This finding provides evidence supporting our claim that the positive link between accounting comparability and innovative efficiency is driven by subject firms' learning of the mapping of peer firms' R\&D expenditures onto peer firms' future cash flows.

To further identify the channel through which subject firms' learning takes place with respect to peer firms' innovative activity, we estimate Eq. (8) using only peer firms that have been innovatively successful, and hence are featured in the NBER patent database. We reason that innovative peer firms provide the subject firms with greater scope for learning about the lead-lag relationship between $R \& D$ expenditures and future period cash flows and earnings. To ensure consistency with the analysis in Panel A, we compute accounting comparability following the procedures set out in Section 4.3 but consider only innovatively successful peer firms (i.e. 
granted at least one patent) when estimating our pro-forma capitalized R\&D earnings comparability measure. Like $\operatorname{COMP}_{i t}{ }_{\text {, }}$ COMPINNOV $_{i t}$ is an indicator variable that takes the value of 1 if accounting comparability with innovatively successful peer firms is in the top quartile and 0 otherwise. If our prediction that innovatively successful peer firms provide subject firms with greater opportunity to learn from their R\&D expenditures is correct, then we expect the coefficient on the $R \& D_{j t} * C O M P I N N O V_{i t}^{\prime}$ interaction term to be positive, larger and more significant than the coefficients on the other interaction terms for cash flows and accruals.

Panel B of Table 4 shows that innovatively successful peer firms' current period earnings components (R\&D, cash flows and accruals) are significantly positively related to those peer firms' future cash flows (both one-period and aggregate four-period ahead). In line with our expectations, only the coefficient on the $R \& D_{j t} * C O M P I N N O V_{i t}^{\prime}$ interaction term is significantly related to future peer firms' cash flows. Specifically, the coefficient (t-statistic) on $R \& D_{j t} *$ COMPINNOV $_{i t}$ is 0.070 (2.57) when $C F_{i t+1}^{*}$ is the dependent variable and 0.425 (3.08) when $C F_{(i t+1 \text { to } t+4)}^{*}$ is the dependent variable. The coefficients on the $C F_{j t} * C_{0 M P I N N O V}{ }_{i t}$ and $A_{C C} * C_{j t}$ COMPINNOV ${ }_{i t}$ interaction terms, although positive, are much smaller and not significantly different from zero.

The main takeaway from Table 4 is that accounting comparability enhances the ability of subject firms to predict peer firms' future cash flows using their current earnings components. Specifically, accounting comparability facilitates a firm's learning from peer firms' current period R\&D expenditures, since higher accounting comparability allows a firm to more accurately predict peer firms' future cash flows from current R\&D expenditures. This relationship is particularly true for peer firms that are innovatively successful (i.e., firms that receive patents). 
$<<$ Insert Table 4 around here >>

The validity of cash flow predictive ability being an important channel for enhancing the relationship between accounting comparability and innovative efficiency of subject firms depends on being able to demonstrate an association between subject firms' innovative efficiency and improved predictive ability of peer firms' future cash flows. Table 5 shows the results for our cash flow forecast accuracy analysis. In this analysis, we investigate whether higher subject firms' cash flow forecast accuracy of peer firms' future cash flows is associated with greater innovative efficiency of subject firms. Consistent with our predictions, in a modified version of Eq. (7) that includes cash flow forecast accuracy $\left(C F_{-} F A\right)$ as an additional explanatory variable, we find that the coefficient on $C F \_F A$ is positive and significant when it is calculated for the period $t+1$ (columns 1 and 2) and for the period $t+1$ to $t+4$ (columns 3 and 4). Further, our measure of accounting comparability, COMP, is positive and significant for all specifications. These results suggest accounting comparability not only has a direct effect on innovative efficiency as outlined in Section 3.1, but also an indirect effect by enhancing the ability of subject firms to predict peer firms' future cash flows over both short and long forecast horizons using peer firms' current period earnings components, and in particular R\&D expenditures.

\section{$<<$ Insert Table 5 around here $>>$}

\subsection{Assessing the moderating effect of accounting quality on the relationship between accounting comparability and innovative investment efficiency}

In this section we examine whether the effect of accounting comparability on innovative efficiency is stronger when accounting quality is higher. ${ }^{24}$ To test whether this is true, we include

\footnotetext{
${ }^{24}$ Note that for this analysis, we treat accounting quality, proxied by $S T D A Q$, as a variable that conditions the effects of accounting comparability on firms' innovative efficiency. Therefore, we are interested in testing the significance
} 
an interaction between $S T D A Q$ and accounting comparability, $C O M P * S T D A Q$, in Eq. (7). The coefficient on the interaction term directly tests hypothesis 3 and captures the incremental effect of accounting quality on the relation between accounting comparability (COMP) and innovative efficiency. Table 6 shows the results for this test. When we interact accounting quality with accounting comparability, we find the coefficient on the interaction terms is positive and significant for both measures of innovative efficiency, consistent with hypothesis 3 .

\section{$<<$ Insert Table 6 around here >>}

\subsection{Innovative versus non-innovative peers}

In our base model, accounting comparability is constructed using industry peers that include a mix of innovative and non-innovative firms. Thus, the prior analysis does not distinguish between learning from peer firms that are successful innovators and learning from non-innovative peer firms. To test whether the effect of accounting comparability on innovative efficiency is greater (less) if peer firms are innovators (non-innovators), we split peer firms into two groups. The Innovative Peer Sample consists of firms granted at least one patent during the period covered by the NBER patent database, while the Non-Innovative Peer Sample consists of firms not featured in this database.

To test hypothesis 4, for each subject firm-year observation, we substitute COMP in Eq. (7) with two measures of accounting comparability: COMPINNOV, computed using the Innovative Peer Sample and COMPNONINNOV, computed using the Non-Innovative Peer Sample. Table 7 shows the results of this test. We find a positive and statistically significant association between COMPINNOV and innovative efficiency, but we do not find a similar relation between COMPNONINNOV and our measures of innovative efficiency. Consistent with 
hypothesis 4 , these results suggest subject firms learn more effectively and are more innovatively efficient when peer firms are themselves successful innovators and subject firms have greater accounting comparability with innovatively successful peer firms.

$$
<<\text { Insert Table } 7 \text { around here >> }
$$

\section{Conclusion}

We predict that having greater accounting comparability with industry peers facilitates a firm's learning from peer firms' innovative investments leading to better R\&D investments. Using a large sample of patent and citation data for U.S. firms for the period 1992-2006, we find that accounting comparability based on the mapping of stock returns onto pro-forma capitalized $R \& D$ earnings is positively associated with innovative efficiency measured by the number of patents issued scaled by $R \& D$ expenditures and by the cumulative citations on those patents scaled by R\&D expenditures.

We find greater accounting comparability enhances the ability of firms to predict peer firms' future cash flows using peer firms' current period earnings components, in particular the R\&D component, over both the short and long horizons. Further, we find that the ability to accurately predict future cash flows of peer firms is positively associated with innovative efficiency of subject firms. These results suggest that one way that accounting comparability enhances innovative efficiency is through the increased predictive ability of future cash flows of peer firms.

In cross-sectional tests, we find the association between accounting comparability and innovative efficiency is stronger when industry accounting (i.e., accrual) quality is higher and when peers are innovative. Specifically, these findings suggest subject firms learn more about 
innovative opportunities when peer firms produce higher quality financial statements and when peer firms are themselves successful innovators.

Our results underscore the importance of accounting comparability in enhancing firms' capital allocation decisions. Specifically, we show that accounting comparability facilitates learning about innovation opportunities (R\&D investments) and successful outcomes from those investments that generate future cash flows. Through better learning, firms make better capital allocation decisions, thus increasing successful innovations for each dollar spent. 


\section{APPENDIX 1}

\section{CALCULATING EARNINGS ADJUSTED FOR PRO-FORMA R\&D CAPITALIZATION}

To calculate the pro-forma earnings adjusted for $\mathrm{R} \& \mathrm{D}$ capitalization (hereafter, proforma capitalized $R \& D$ earnings), we use a modified version of the procedure adopted in Lev and Sougiannis (1996) (hereafter, LS). Conceptually, the LS procedure assumes that each period's R\&D expenditures have a delayed and prolonged impact on multiple future periods of a firm's economic performance. Therefore, one can think of multiple lagged R\&D expenditures as having an impact on current period firm profitability with the weights attached to each lagged $R \& D$ expenditure being a function of the degree of correlation between the lagged period's $R \& D$ expenditures and the profitability reported in the current period. As such, LS's application of the Almon (1965) disributed lag model treats R\&D expenditures as investments in intangible assets by capitalizing past and current $R \& D$ expenditures and amortizing these capitalized $R \& D$ expenditures over time. Similar to the depreciation of tangible assets such as property, plant and equipment, the amortization of R\&D-based intangible assets depends on the appropriated benefits of such assets to a particular future period's profitability.

The following discussion describes how we operationalize the procedure described above. To estimate the effect of lagged R\&D expenditures on current period earnings, we build on equation (4) in LS and estimate the following time-series regression: ${ }^{25}$

$$
\text { NI_RD } D_{v t}=\alpha_{0}+\sum_{k} \alpha_{1, v t-k} R D_{v t-k}+\varepsilon_{v t}
$$

In equation (1A), NI_RD is net income before extraordinary items after adding back $\mathrm{R} \& \mathrm{D}$ expenditures net of tax for industry $v$ in year $t$, scaled by concurrent sales; ${ }^{26}$ and $R D$ is the

\footnotetext{
${ }^{25}$ LS include total assets scaled by sales and annual advertising expenses scaled by sales in their equation. We do not include these variables in equation (1A) because we are only concerned with the effect of R\&D expenditure on income.

${ }^{26}$ We add after-tax R\&D expenditure to net income before extraordinary items. In our calculations we assume a 35 percent tax rate.
} 
R\&D expenditure scaled by concurrent sales in current dollars. We drop firm-year observations with missing or zero R\&D expenditures because subject firms cannot observe these peer firms' $R \& D$ expenditures and thus cannot compute their amortization rates in years with missing $R \& D$ values. Furthermore, we follow LS and drop observations for which R\&D expenditure scaled by sales is less than 2 percent. Finally, to ensure that our sample for this analysis consists of those firms for which R\&D expenditures give rise to successful outcomes, we only keep firms that are featured in the NBER patent database, i.e., firms that have been granted one or more patents. To mitigate the simultaneity issue that can arise when estimating equation (1A) at the firm level, we estimate equation (1A) using aggregate two-digit SIC industry level data, where the variables are calculated as the market-weighted average values for each industry-year. This aggregation method is similar to that adopted by Konchitchki and Patatoukas (2014).

Estimating the effect of R\&D on earnings is challenging because firms can have multiple research projects at the same time and each research project can potentially yield future benefits. In addition, due to the uncertain nature of innovative activities, there is no guarantee that $R \& D$ investments in one period will yield future benefits; but once such R\&D investments result in an innovation (patent), that innovation can provide benefits over an extended period of time. As such, the effect of $R \& D$ expenditures on earnings is rolling and cumulative in nature with these expenditures having a delayed and prolonged impact. The Almon (1965) finite distributed lag model is ideal for this situation. By modeling the current benefits (profitability) as the result of cumulative past $R \& D$ expenditures, the Almon model can accommodate this dynamic nature of innovative activities.

We estimate equation (1A) using the Almon distributed lag model for each two-digit SIC code industry $v$ where the coefficent estimates of the aggregate series, $\sum_{k} \alpha_{1, v t-k}$, capture the 
$\mathrm{R} \& \mathrm{D}$ lag structure for that industry where $k$ refers to the lagged period's $\mathrm{R} \& \mathrm{D}$ expenditure that is being associated with current period $t$ 's earnings. In addition to its ability to capture the rolling and cumulative effect of lagged R\&D expenditures on current period earnings, the Almon lag model mitigates multicollinearity concerns that result from trying to estimate a long vector of parameter values when lagged $R \& D$ expenditures stated as a percentage of sales are sticky. It does this by reducing the number of regressors needed to estimate the lag structure of R\&D from $k+1$ to $p+1$ by ex-ante imposing a polynomial form of degree $p$ on the relationship between the regressors and the number of lagged periods. The polynominal degree $p$ determines the shape of the lag structure distribution for the series of lagged R\&D expenditures. Degree of one produces an increasing or decreasing lag distribution, while degrees of two and three produce an increasing (decreasing) then decreasing (increasing) lag distribution. Prior studies using the Almon lag model on R\&D expenditures tend to use polynomial degrees of two or three because they produce lag distributions that fit the economic expectation that the impact of R\&D expenditures on economic output initially increases then decreases due to new technology becoming obsolete over time (Lev 1994; and Lev and Sougiannis 1996). Consistent with LS, we choose polynomial degrees of two or three for our analysis.

Another design choice we make when using the Almon model is the number of lagged R\&D expenditures that are expected to impact earnings, i.e., the lag length. Given a polynomial degree, we choose the lag length that gives an increasing-then-decreasing lag distribution, that ends with the last lag value that is significant, and that maximizes the adjusted R-squared. Because each series has a different lag distribution, we choose a different combination of polynomial degree and lag length for each two-digit SIC industry. 
Our estimation of the lead-lag structure between R\&D and profits differs from that in LS in one important aspect. LS estimate the lead-lag structure at the firm level, using the cumulative time series of each firm in each year, requiring each firm to have at least 10 years of available data. We, on the other hand, estimate the lead-lag structure at the industry level. We do this because we assume that innovatively successful firms in the same industry have similar mapping functions of R\&D efforts into future profits, and that the industry-level lead-lag strucuture is the average of the lead-lag structures at the firm level. We also do not use the two-stage least square regression using the average $R \& D$ expenditures of industry peers as instrumental variables because our aggregate measures of $R \& D$ and earnings mitigate the simultaneity issue pointed out by LS.

After estimating the distribution of lagged $R \& D$ expenditures with respect to current earnings for each two-digit SIC industry, we retain the coefficient estimates that are statisitcally significant at the 10 percent level and compute the sum of the significant R\&D coefficients $\sum_{k} \hat{\alpha}_{1, v t-k}$. The estimated $\hat{\alpha}_{1, v t-k}$ captures the effect of R\&D expenditure in year $\mathrm{t}-k$ on earnings in year $t$, while $\sum_{k} \hat{\alpha}_{1, v t-k}$ captures the total effect of $\mathrm{R} \& \mathrm{D}$ expenditures in prior years on earnings in year $t$. The amortization rate, $\delta_{v t-k}$, is the relative weight of the benefit of past R\&D invesments on current earnings. We calculate $\delta_{v t-k}$ at the industry level as follows:

$$
\delta_{v t-k}=\hat{\alpha}_{1, v t-k} / \sum_{k} \hat{\alpha}_{1, v t-k}
$$

Table 1A illustrates the lag structures of two industries along with their amortization rates that exhibit widely different lag structures. For the Chemicals and Applied Products industry (SIC 28) the impact of lagged R\&D expenditures on current period profitability starts after one year and the effect lasts for an average of 16 years. On the other hand, for the Fabricated Metal 
Products industry (SIC 34), the impact of lagged R\&D expenditures on current period profitability starts after three years and the average duration is only three years.

$$
\text { <<Insert Table 1A here>> }
$$

We use the industry-level $\delta_{v t-k}$ to calculate the annual R\&D amortization for each firm in that industry. We then compute the annual R\&D amortization for firm $i$ in industry $v$ in year $t$, $R A_{i v t}$, as follows:

$$
R A_{i v t}=\sum_{k} \delta_{v t-k} R D_{i v t-k}
$$

Finally, we adjust earnings for R\&D capitalization, Adjusted Earnings, by adding aftertax R\&D expenditures $(R D)$ to net income before extraordinary items and subtracting after-tax $\mathrm{R} \& \mathrm{D}$ amortization $(R A)$ as shown in equation $(4 \mathrm{~A}):{ }^{27}$

$$
\text { Adjusted Earnings }_{i v t}=\text { Reported Earnings } \text { Evt }_{i v t}+R D_{i v t}-R A_{i v t}
$$

\footnotetext{
${ }^{27}$ Equations (2A), (3A), and (4A) are equivalent to equations (5), (6), and (7) in LS.
} 
Table 1A

Examples of industry-level lag structures and amortization rates

\begin{tabular}{|l|c|c|c|c|}
\hline $\begin{array}{l}\text { Industry } \\
\text { Two-digit } \\
\text { SIC code }\end{array}$ & \multicolumn{2}{|c|}{$\begin{array}{c}\text { Chemical and Applied } \\
\text { Products }\end{array}$} & \multicolumn{2}{c|}{$\begin{array}{c}\text { Fabricated Metal } \\
\text { Products }\end{array}$} \\
\hline Period & $\hat{\alpha}_{1, v t-k}$ & $\delta_{v t-k}$ & $\hat{\alpha}_{1, v t-k}$ & $\delta_{v t-k}$ \\
\hline & & & & \\
\hline $\mathrm{t}$ & & & & \\
\hline $\mathrm{t}-1$ & 0.478 & 0.037 & & \\
\hline $\mathrm{t}-2$ & 0.555 & 0.043 & & 0.021 \\
\hline $\mathrm{t}-3$ & 0.569 & 0.044 & 0.270 & 0.021 \\
\hline $\mathrm{t}-4$ & 0.543 & 0.042 & 0.272 & 0.020 \\
\hline $\mathrm{t}-5$ & 0.498 & 0.039 & 0.266 & \\
\hline $\mathrm{t}-6$ & 0.451 & 0.035 & & \\
\hline $\mathrm{t}-7$ & 0.415 & 0.032 & & \\
\hline $\mathrm{t}-8$ & 0.398 & 0.031 & & \\
\hline $\mathrm{t}-9$ & 0.406 & 0.032 & & \\
\hline $\mathrm{t}-10$ & 0.440 & 0.034 & & \\
\hline $\mathrm{t}-11$ & 0.496 & 0.039 & & \\
\hline $\mathrm{t}-12$ & 0.568 & 0.044 & & \\
\hline $\mathrm{t}-13$ & 0.645 & 0.050 & & \\
\hline $\mathrm{t}-14$ & 0.713 & 0.056 & & \\
\hline $\mathrm{t}-15$ & 0.752 & 0.059 & & \\
\hline $\mathrm{t}-16$ & 0.742 & 0.058 & & \\
\hline & & & & \\
\hline
\end{tabular}

Table 1A: Examples of industry-level lag structures and amortization rates. $\hat{\alpha}_{1, v t-k}$, the parameter estimates from Eq. (1A)., measures the correlation between R\&D expenditures of industry $\mathrm{v}$ at time $\mathrm{t}-\mathrm{k}$ and earnings of industry $\mathrm{v}$ at time t. $\delta_{v t-k}$, computed from Eq. (2A), measures the amortization rate of industry $v$ at time $t-k$. 


\section{APPENDIX 2: VARIABLE DEFINITIONS}

\section{Variable}

Dependent variables IE_CITATIONS

IE_PATENTS

\section{Definition}

Investment Efficiency - Citations. Computed as adjusted citations scaled by R\&D capital, where adjusted citations is the sum of citations per year for patents granted to a company in a particular year scaled by mean number of citations for the industry for that year.

Investment Efficiency - Patents. Computed as the sum of patents granted to a company in a year scaled by $R \& D$ capital.

\section{Main independent variable}

COMP

Accounting comparability calculated as in De Franco et al. (2011) but using Adjusted Earnings instead of net income before extraordinary items. Adjusted Earnings is net income before extraordinary items and $\mathrm{R} \& \mathrm{D}$ expenditure adjusted for $\mathrm{R} \& \mathrm{D}$ amortization.

\section{Other independent variables}

STDAQ

Accounting quality is measured as the standard deviation of residuals over the same 16 quarters used to calculate $C O M P$ obtained from the following regression model: $\Delta W C_{t}=b_{0}+b_{1} C F O_{t-1}+b_{2} C F O_{t}+$ $b_{3} C_{F O} O_{t+1}+b_{4} \Delta$ Sales $_{t}+b_{5} P P E_{t}+\varepsilon_{t}$, multiplied by minus one and standardized so that it has a mean of 0 and a standard deviation of 1 .

CAPINT

Capital Intensity. Computed as the logarithmic transformation of total assets scaled by number of employees.

CORR

Correlation. Computed as the average correlation of the firm monthly returns with the respective returns for firms with the same two-digit SIC code in CRSP.

IO

Institutional holdings. Computed as the fraction of firm shares outstanding owned by institutional shareholders.

LEV

Leverage. Computed as long-term debt scaled by shareholders' equity.

MTB

Market-to-book ratio. Computed as market value of equity scaled the book value of equity. 
OCFVOL

RDS

ROA

SIZE

SYNC

TOBINQ
Cash flow volatility. Computed as the operating cash flow coefficient of variation over the 24 quarters used in calculating COMP and ranked into deciles.

Research and development. Calculated as the logarithmic transformation of R\&D expenses scaled by lagged total assets.

Return on assets. Computed as income before extraordinary items scaled by lagged total assets.

Size. Calculated as the logarithmic transformation of total assets.

Synchronicity. Calculated as the adjusted R-squared from a market model OLS.

Tobin's q. Calculated as the sum of the market value of equity and debt scaled by total assets.

\section{Additional variables used in further analyses}

$\mathrm{ACC}$

$\mathrm{CF}$

$\mathrm{CF}^{*}$

CF_FA

COMP'

COMPINNOV
Accruals. Computed as the difference between earnings and net operating cash flows, scaled by average total assets.

Net operating cash flows for the period scaled, scaled by average total assets.

Net operating cash flows before deducting R\&D expenditures for the period, scaled by average total assets.

We compute the forecast accuracy for predicting both one-year ahead and aggregate four-year ahead cash flows for peer firms in subject firm $i$ 's two-digit SIC industry. Forecast accuracy for predicting oneyear ahead peer cash flows is computed using the residuals from Eq. (8) when $C F^{*}{ }_{j t+1}$ is the dependent variable while, forecast accuracy for predicting aggregate peer firm cash flows is computed using the residuals from Eq. (8) when $C F^{*}{ }_{j t+1}$ to $t+4$ is the dependent variable. In both cases forecast accuracy for each subject firm is computed as the absolute value of the median residual scaled by the predicted cash flow multiplied by minus one so that a more positive measure of forecast accuracy, indicates greater predictive ability.

An indicator variable that takes the value of 1 when accounting comparability is in the top quartile and 0 otherwise.

An indicator variable that takes the value of 1 when accounting comparability with innovatively successful peer firms is in the top 
quartile and 0 otherwise.

COMPINNOV

COMPNONINNOV

$\mathrm{R} \& \mathrm{D}$
Accounting comparability with innovative peers calculated similar to $C O M P$ but including only peer firms which have at least one patent in the NBER patent dataset.

Accounting comparability with non-innovative peers calculated similar to $C O M P$ but including only peer firms which do not feature in the NBER patent dataset.

R\&D expenditures scaled by average total assets. $R \& D$ expenditures are Compustat annual data item XRD, which is research and development expense reported on the income statement.

All continous variables are winsorized at the 5 percent level for the whole sample. 


\section{REFERENCES}

Aghion, P., S. Bond, A. Klemm, and I. Marinescu. 2004. Technology and financial structure: Are innovative firms different? Journal of the European Economic Association 2 (2-3): 277288.

Aghion, P., J. Van Reenen, and L. Zingales. 2013. Innovation and institutional ownership. American Economic Review 103 (1): 277-304.

Almon, S. 1965. The distributed lag between capital appropriations and expenditures. Econometrica 33 (1): 178-196.

Atanassov, J. 2013. Do hostile takeovers stifle innovation? Evidence from antitakeover legislation and corporate patenting. Journal of Finance 68 (3): 1097-1131.

Atanassov, J., V. Nanda, and A. Seru. 2007. Finance and innovation: The case of publicly traded firms. Working paper, University of Oregon, Georgia institute of Technology, and University of Chicago.

Badertscher, B., N., Shroff, and H.D. White. 2013. Externalities of public firm presence: Evidence from private firms' investment decisions. Journal of Financial Economics 109 (3): $682-706$.

Barth, M.E., Cram D.P., and K.K. Nelson. 2001. Accruals and the prediction of future cash flows. The Accounting Review 76 (1): 27-58.

Beatty, A., S. Liao, and J.J. Yu. 2013. The spillover effect of fraudulent financial reporting on peer firms' investments. Journal of Accounting and Economics 55 (2-3): 183-205.

Bhagat, S., and I. Welch. 1995. Corporate research \& development investments international comparisons. Journal of Accounting and Economics 19 (2-3): 443-470.

Biddle, G.C., and G. Hilary. 2006. Accounting quality and firm-level capital investment. The Accounting Review 81 (5): 963-982.

Biddle, G.C., G. Hilary, and R. S. Verdi. 2009. How does financial reporting quality relate to investment efficiency? Journal of Accounting and Economics 48 (2-3): 112-131.

Brochet, F., Jagolinzer, A.D., and E.J. Riedl. 2013. Mandatory IFRS adoption and financial statement comparability. Contemporary Accounting Research 30 (4): 1373-1400.

Chan, L.K.C., J. Lakonishok, and T. Sougiannis. 2001. The stock market valuation of research and development expenditures. Journal of Finance 56 (6): 2431-2456.

Chang, X., G. Hilary, J.-K. Kang, and W. Zhang. 2015. Innovation, managerial myopia, and financial reporting, INSEAD Working Paper No. 2013/35/AC.

Chen, C. W., Collins, D. W., Kravet, T. D., \& Mergenthaler, R. D. 2018. Financial statement comparability and the efficiency of acquisition decisions. Contemporary Accounting Research 35 (1): 164-202. 
De Franco, G., S.P. Kothari, and R.S. Verdi. 2011. The benefits of financial statement comparability. Journal of Accounting Research 49 (4): 895-931.

Dechow, M.P. 1994. Accounting earnings and cash flows as measures of firm performance: The role of accounting accruals. Journal of Accounting and Economics 18 (1): 3-42.

Dechow, M.P., and I.D. Dichev. 2002. The quality of accruals and earnings: The role of accural estimation errors. The Accounting Review 77 (s-1): 35-59

Fang, W.V., X. Tian, and T. Sheri. 2014. Does stock liquidity enhance or impede firm innovation? Journal of Finance 69 (5): 2085-2125.

FASB. 2010. Statement of Financial Accounting Concepts No. 8: Conceptual Framework for Financial Reporting.

Ferreira, D., Gustavo M., and S. Andre. 2014. Incentives to innovate and the decision to go public or private. Review of Financial Studies 27 (1): 256-300.

Gu, F. 2005. Innovation, future earnings, and market efficiency. Journal of Accounting, Auditing and Finance 20 (4): 385-418.

Hall, B.H., A. Jaffe, and M. Trajtenberg. 2001. The NBER patent citation data file: lessons, insights and methodological tools. Unpublished NBER Working Paper 8498.

Hall, B.H., A. Jaffe, and M. Trajtenberg. 2005. Market value and patent citations. RAND Journal of Economics 36 (1): 16-38.

Harhoff, D., F. Narin, F.M. Scherer, and K. Vopel. 1999. Citation frequency and the value of patented inventions. Review of Economics and Statistics 81 (3): 511-515.

He, J. and X. Tian. 2013. The dark side of analyst coverage: The case of innovation. Journal of Financial Economics 109 (3): 856-878.

Hirshleifer, D., S.S. Lim, and S. H. Teoh. 2011. Limited investor attention and stock market misreactions to accounting information. Review of Asset Pricing Studies 1 (1): 35-73.

Hirshleifer, D., H.P. Hsu, and D. Li. 2013. Innovative efficiency and stock returns. Journal of Financial Economics 107 (3): 632-654

Horton, J, G. Serafeim, and I. Serafeim. 2013. Does mandatory IFRS adoption improve the information environment. Contemporary Accounting Research 30 (1): 388-423.

Hsu, P. H. 2009. Technological innovations and aggregate risk premiums. Journal of Financial Economics 94 (2): 264-279.

Hsu, P.H., X. Tian, and Y. Xu. 2014. Financial development and innovation: Cross-country evidence. Journal of Financial Economics 112 (1): 116-135.

Jones, J.J. 1991. Earnings management during import relief investigations. Journal of Accounting Research 29 (2): 193-228. 
Konchitchki, Y., \& Patatoukas, P. N. 2014. Accounting earnings and gross domestic product. Journal of Accounting and Economics 57 (1): 76-88.

Kothari, S.P., T.E. Laguerre, and A.J. Leone. 2002. Capitalization versus expensing: Evidence on the uncertainty of future earnings from capital expenditures versus R\&D outlays. Review of Accounting Studies 7 (4): 355-382.

Lev, B., and T. Sougiannis. 1996. The capitalization, amortization, and value-relevance of R\&D. Journal of Accounting and Economics 21 (1): 107-138.

Lev, B., B. Sarath, and T. Sougiannis. 2005. R\&D reporting biases and their consequences. Contemporary Accounting Research 22 (4): 977-1026.

Li, L. 2012. The impact of accounting for research and development on innovation. Ph.D. thesis, Massachusetts Institute of Technology.

Livdan, D., H. Sapriza, and L. Zhang. 2009. Financially constrained stock returns. Journal of Finance 64 (4): 1827-1862.

McNichols, M. 2002. The quality of accruals and earnings: The role of accrual estimation errors: Discussion. The Accounting Review 77 (s-1): 61-69.

Nanda R. and M. Rhodes-Kropf. 2013. Investment cycles and startup innovation. Journal of Financial Economics 110 (2): 403-418.

Nanda, R., and M. Rhodes-Kropf. 2017. Financing risk and innovation. Management Science 63 (4): $901-918$.

Pandit, S., C.E. Wasley, and T. Zach. 2011. The effect of R\&D inputs and outputs on the relation between the uncertainty of future operating performance and R\&D expenditures. Journal of Accounting, Auditing, and Finance 26 (1): 121-144.

Schipper, K. 2003. Principles-based accounting standards. Accounting Horizons 17 (1): 61-72.

SEC. 2000. SEC Concept Release: International Accounting Standards. Available at http://www.sec.gov/rules/concept/34-42430.htm.

Seru, A. 2014. Firm boundaries matter: Evidence from conglomerates and R\&D activity. Journal of Financial Economics 111 (2): 381-405.

Shroff, N., R. Verdi, and Y. Gwen. 2013. Information environment and the investment decisions of multinational corporations. The Accounting Review 89 (2): 759-790.

Solow, R. 1957. Technological change and the aggregate production function. Review of Economics and Statistics 39: 312-320.

Sougiannis, T. 1994. The accounting based valuation of corporate R\&D. The Accounting Review 69 (1): 44-68.

Tian, X. and T.Y. Wang. 2014. Tolerance for failure and corporate innovation. Review of Financial Studies 27 (1): 211-255. 
Trajtenberg, M. 1990. A penny for your quotes: patent citations and the value of innovations. RAND Journal of Economics 21 (1): 172-187. 
TABLE 1

\section{DISTRIBUTION OF OBSERVATIONS}

PANEL A: Distribution of observations by year

\begin{tabular}{cccc}
\hline YEAR & FREQ. & PERCENT & CUM. \\
& & & \\
1992 & 444 & 4.54 & 4.54 \\
1993 & 519 & 5.31 & 9.85 \\
1994 & 526 & 5.38 & 15.24 \\
1995 & 548 & 5.61 & 20.85 \\
1996 & 585 & 5.99 & 26.83 \\
1997 & 604 & 6.18 & 33.01 \\
1998 & 649 & 6.64 & 39.65 \\
1999 & 639 & 6.54 & 46.19 \\
2000 & 640 & 6.55 & 52.74 \\
2001 & 635 & 6.5 & 59.24 \\
2002 & 741 & 7.58 & 66.82 \\
2003 & 798 & 8.17 & 74.99 \\
2004 & 821 & 8.4 & 83.39 \\
2005 & 848 & 8.68 & 92.07 \\
2006 & 775 & 7.93 & 100 \\
& & & \\
Total & 9,772 & 100 & \\
\hline
\end{tabular}


PANEL B: Distribution of observations by industry

\begin{tabular}{|c|c|c|c|c|}
\hline $\begin{array}{l}\text { Two-digit } \\
\text { SIC code }\end{array}$ & Industry Name & Freq. & Percent & Cum. \\
\hline 10 & Metal Mining & 7 & 0.07 & $0.0^{\circ}$ \\
\hline 13 & Oil and Gas Extraction & 61 & 0.62 & 0. \\
\hline 14 & Mining and Quarrying of Non-metallic Minerals, Except Fuels & 2 & 0.02 & 0.72 \\
\hline 15 & Construction - General Contractors \& Operative Builders & 1 & 0.01 & 0.73 \\
\hline 16 & Heavy Construction, Except Building Construction, Contractor & 6 & 0.06 & 0.79 \\
\hline 20 & Food and Kindred Products & 94 & 0.96 & 1.75 \\
\hline 22 & Textile Mill Products & 49 & 0.5 & 2.25 \\
\hline 24 & Lumber and Wood Products, Except Furniture & 8 & 0.08 & 2.33 \\
\hline 25 & Furniture and Fixtures & 86 & 0.88 & 3.2 \\
\hline 26 & Paper and Allied Products & 169 & 1.73 & 4.94 \\
\hline 27 & Printing, Publishing and Allied Industries & 33 & 0.34 & 5.28 \\
\hline 28 & Chemicals and Allied Products & 1,809 & 18.51 & 23.79 \\
\hline 29 & Petroleum Refining and Related Industries & 98 & 1 & 24.8 \\
\hline 30 & Rubber and Miscellaneous Plastic Products & 176 & 1.8 & 26. \\
\hline 31 & Leather and Leather Products & 7 & 0.07 & 26.67 \\
\hline 32 & Stone, Clay, Glass, and Concrete Products & 62 & 0.63 & 27.3 \\
\hline 33 & Primary Metal Industries & 178 & 1.82 & 29.12 \\
\hline 34 & Fabricated Metal Products & 208 & 2.13 & 31.25 \\
\hline 35 & Industrial and Commercial Machinery and Computer Equipment & 1,572 & 16.09 & 47.34 \\
\hline 36 & Electronic \& Other Electrical Equipment \& Components & 1,799 & 18.41 & 65.75 \\
\hline 37 & Transportation Equipment & 417 & 4.27 & 70.02 \\
\hline 38 & Measuring, Photographic, Medical, \& Optical Goods, \& Clocks & 1,705 & 17.45 & 87.46 \\
\hline 39 & Miscellaneous Manufacturing Industries & 149 & 1.52 & 88.99 \\
\hline 48 & Communications & 37 & 0.38 & 89.37 \\
\hline 49 & Electric, Gas and Sanitary Services & 13 & 0.13 & 89.5 \\
\hline 50 & Wholesale Trade - Durable Goods & 47 & 0.48 & 89.98 \\
\hline 51 & Wholesale Trade - Nondurable Goods & 35 & 0.36 & 90.34 \\
\hline 58 & Eating and Drinking Places & 5 & 0.05 & 90.39 \\
\hline 59 & Miscellaneous Retail & 14 & 0.14 & 90.53 \\
\hline 73 & Business Services & 731 & 7.48 & 98.01 \\
\hline 78 & Motion Pictures & 8 & 0.08 & 98. \\
\hline 79 & Amusement and Recreation Services & 7 & 0.07 & 98.17 \\
\hline 80 & Health Services & 39 & 0.4 & 98.57 \\
\hline \multirow[t]{2}{*}{87} & Engineering, Accounting, Research, and Management Services & 140 & 1.43 & 10 \\
\hline & Total & 9,772 & 100 & \\
\hline
\end{tabular}

Table 1: Panel A shows the distribution of observations over the sample period and Panel B shows the distribution of observations by industry. 
TABLE 2

\section{SUMMARY STATISTICS}

PANEL A: Distributional Statistics

\begin{tabular}{lrrrrr}
\hline VARIABLE & \multicolumn{1}{l}{ P25 } & MEAN & \multicolumn{1}{l}{ P50 } & P75 & Std. Dev. \\
& & & & & \\
IE_PATENTS & 0.004 & 0.162 & 0.067 & 0.194 & 0.247 \\
IE_CITATIONS & 0.011 & 0.157 & 0.052 & 0.162 & 0.263 \\
COMP & -3.510 & -2.890 & -2.570 & -2.060 & 1.137 \\
SIZE & 4.157 & 5.844 & 5.730 & 7.406 & 2.036 \\
MTB & 1.543 & 3.200 & 2.464 & 4.121 & 2.245 \\
LEV & 0.000 & 0.354 & 0.148 & 0.507 & 0.483 \\
CAPINT & 4.878 & 5.429 & 5.357 & 5.968 & 0.750 \\
RDS & -3.610 & -2.839 & -2.715 & -1.974 & 1.107 \\
ROA & -0.049 & -0.002 & 0.042 & 0.093 & 0.149 \\
IO & 0.087 & 0.400 & 0.424 & 0.670 & 0.297 \\
STDAQ & -0.356 & 0.000 & 0.226 & 0.616 & 1.000 \\
TOBINQ & 0.977 & 1.904 & 1.484 & 2.476 & 1.231 \\
SYNC & 0.034 & 0.094 & 0.078 & 0.136 & 0.072 \\
CORR & 0.107 & 0.162 & 0.153 & 0.212 & 0.074 \\
OCFVOL & 0.222 & 0.500 & 0.556 & 0.778 & 0.319 \\
\hline
\end{tabular}




\section{PANEL B: Pearson Correlation Matrix}

\begin{tabular}{|c|c|c|c|c|c|c|c|c|c|c|c|c|c|c|c|c|}
\hline & VARIBALE & 1 & 2 & 3 & 4 & 5 & 6 & 7 & 8 & 9 & 10 & 11 & 12 & 13 & 14 & 15 \\
\hline 1 & IE_PATENTS & 1.000 & & & & & & & & & & & & & & \\
\hline \multirow[t]{2}{*}{2} & IE_CITATIONS & 0.453 & 1.000 & & & & & & & & & & & & & \\
\hline & & 0.000 & & & & & & & & & & & & & & \\
\hline \multirow[t]{2}{*}{3} & COMP & 0.094 & 0.024 & 1.000 & & & & & & & & & & & & \\
\hline & & 0.000 & 0.020 & & & & & & & & & & & & & \\
\hline \multirow[t]{2}{*}{4} & SIZE & -0.225 & -0.437 & 0.232 & 1.000 & & & & & & & & & & & \\
\hline & & 0.000 & 0.000 & 0.000 & & & & & & & & & & & & \\
\hline \multirow[t]{2}{*}{5} & MTB & -0.028 & -0.050 & -0.045 & -0.005 & 1.000 & & & & & & & & & & \\
\hline & & 0.006 & 0.000 & 0.000 & 0.643 & & & & & & & & & & & \\
\hline \multirow[t]{2}{*}{6} & LEV & -0.060 & -0.119 & 0.028 & 0.339 & 0.087 & 1.000 & & & & & & & & & \\
\hline & & 0.000 & 0.000 & 0.006 & 0.000 & 0.000 & & & & & & & & & & \\
\hline \multirow[t]{2}{*}{7} & CAPINT & -0.159 & -0.236 & -0.165 & 0.249 & 0.166 & -0.001 & 1.000 & & & & & & & & \\
\hline & & 0.000 & 0.000 & 0.000 & 0.000 & 0.000 & 0.890 & & & & & & & & & \\
\hline \multirow[t]{2}{*}{8} & RDS & -0.108 & -0.101 & -0.256 & -0.397 & 0.322 & -0.303 & 0.186 & 1.000 & & & & & & & \\
\hline & & 0.000 & 0.000 & 0.000 & 0.000 & 0.000 & 0.000 & 0.000 & & & & & & & & \\
\hline \multirow[t]{2}{*}{9} & ROA & 0.026 & -0.048 & 0.350 & 0.401 & -0.109 & -0.014 & -0.158 & -0.388 & 1.000 & & & & & & \\
\hline & & 0.010 & 0.000 & 0.000 & 0.000 & 0.000 & 0.170 & 0.000 & 0.000 & & & & & & & \\
\hline \multirow[t]{2}{*}{10} & $\mathrm{IO}$ & -0.119 & -0.258 & 0.226 & 0.493 & -0.006 & 0.134 & 0.069 & -0.181 & 0.312 & 1.000 & & & & & \\
\hline & & 0.000 & 0.000 & 0.000 & 0.000 & 0.570 & 0.000 & 0.000 & 0.000 & 0.000 & & & & & & \\
\hline \multirow[t]{2}{*}{11} & STDAQ & 0.162 & 0.192 & 0.289 & -0.201 & -0.109 & -0.049 & -0.448 & 0.005 & 0.105 & -0.019 & 1.000 & & & & \\
\hline & & 0.000 & 0.000 & 0.000 & 0.000 & 0.000 & 0.000 & 0.000 & 0.616 & 0.000 & 0.062 & & & & & \\
\hline \multirow[t]{2}{*}{12} & TOBINQ & 0.021 & 0.022 & -0.036 & -0.153 & 0.860 & -0.213 & 0.236 & 0.428 & -0.099 & -0.039 & -0.086 & 1.000 & & & \\
\hline & & 0.040 & 0.032 & 0.000 & 0.000 & 0.000 & 0.000 & 0.000 & 0.000 & 0.000 & 0.000 & 0.000 & & & & \\
\hline \multirow[t]{2}{*}{13} & SYNC & -0.188 & -0.336 & -0.065 & 0.514 & 0.046 & 0.054 & 0.343 & 0.037 & 0.086 & 0.341 & -0.228 & 0.033 & 1.000 & & \\
\hline & & 0.000 & 0.000 & 0.000 & 0.000 & 0.000 & 0.000 & 0.000 & 0.000 & 0.000 & 0.000 & 0.000 & 0.001 & & & \\
\hline \multirow[t]{2}{*}{14} & CORR & -0.113 & -0.139 & -0.206 & 0.110 & -0.019 & -0.063 & 0.232 & 0.101 & -0.098 & 0.014 & -0.221 & 0.021 & 0.507 & 1.000 & \\
\hline & & 0.000 & 0.000 & 0.000 & 0.000 & 0.059 & 0.000 & 0.000 & 0.000 & 0.000 & 0.170 & 0.000 & 0.040 & 0.000 & & \\
\hline \multirow[t]{2}{*}{15} & OCFVOL & 0.015 & -0.003 & 0.166 & 0.157 & -0.224 & 0.070 & -0.157 & -0.213 & 0.341 & 0.148 & 0.127 & -0.241 & 0.030 & -0.062 & 1.000 \\
\hline & & 0.151 & 0.759 & 0.000 & 0.000 & 0.000 & 0.000 & 0.000 & 0.000 & 0.000 & 0.000 & 0.000 & 0.000 & 0.003 & 0.000 & \\
\hline
\end{tabular}

Table 2: Summary statistics. Panel A shows distributional statistics while Panel B shows the Pearson correlation matrix, for the variables used in Eq. (7). The sample consists of 9,772 firm-year observations. All variables are defined in Appendix 2. 
TABLE 3

\section{ACCOUNTING COMPARABILITY AND INNOVATIVE EFFICIENCY}

$I E_{i t}=\beta_{0}+\beta_{1}$ COMP $_{i t}+\beta_{2} \operatorname{SIZE}_{i t}+\beta_{3} M T B_{i t}+\beta_{4} L E V_{i t}+\beta_{5} C A P I N T_{i t}+\beta_{6} R D S_{i t}+\beta_{7} R O A_{i t}+$ $\beta_{8} I O_{i t}+\beta_{9} S T D A Q_{i t}+\beta_{10} T O B I N Q_{i t}+\beta_{11} S Y N C_{i t}+\beta_{12}$ CORR $_{i t}+\beta_{13}$ OCFVOL $_{i t}+$ Industry Fixed Effects ${ }_{t}+\varepsilon_{\text {it }}$

\begin{tabular}{|c|c|c|c|c|c|c|}
\hline \multirow[t]{2}{*}{ VARIABLE } & \multicolumn{3}{|c|}{ IE_PATENTS } & \multicolumn{3}{|c|}{ IE_CITATIONS } \\
\hline & Coeff. & & t-Stat & Coeff. & & t-Stat \\
\hline COMP & 0.017 & $* * *$ & 4.71 & 0.010 & $* *$ & 2.49 \\
\hline SIZE & -0.035 & $* * *$ & -8.18 & -0.064 & $* * *$ & -12.09 \\
\hline MTB & -0.005 & & -1.50 & -0.007 & $*$ & -1.81 \\
\hline LEV & 0.007 & & 0.72 & 0.005 & & 0.48 \\
\hline CAPINT & 0.003 & & 0.42 & 0.002 & & 0.18 \\
\hline RDS & -0.056 & $* * *$ & -8.12 & -0.082 & $* * *$ & -10.02 \\
\hline ROA & 0.047 & & 1.44 & 0.036 & & 1.13 \\
\hline IO & -0.037 & $* * *$ & -2.83 & -0.066 & $* * *$ & -4.87 \\
\hline STDAQ & 0.016 & $* * *$ & 3.36 & 0.016 & $* *$ & 2.14 \\
\hline TOBINQ & 0.029 & $* * *$ & 3.41 & 0.035 & $* * *$ & 4.26 \\
\hline SYNC & 0.075 & & 1.13 & -0.063 & & -1.04 \\
\hline CORR & -0.129 & $* *$ & -2.12 & -0.068 & & -0.96 \\
\hline OCFVOL & -0.006 & & -0.49 & 0.005 & & 0.42 \\
\hline Constant & -0.071 & & -1.35 & 1.009 & $* * *$ & 13.77 \\
\hline Industry F.E. & & Yes & & & Yes & \\
\hline S.E. clustered by firm and year & & Yes & & & Yes & \\
\hline Observations & & 9,772 & & & 9,772 & \\
\hline R-squared & & 0.148 & & & 0.32 & \\
\hline Adjusted R-squared & & 0.144 & & & 0.316 & \\
\hline
\end{tabular}

Table 3: Accounting comparability and innovative efficiency. Regression results for Eq. (7). All variables are as defined in Appendix 2. Standard errors are clustered by firm and year. *,** and *** denote significance of two tailed tests at the $10 \%, 5 \%$ and $1 \%$ level of significance respectively. 
TABLE 4

\section{EFFECT OF ACCOUNTING COMPARABILITY ON THE PREDICTIVE ABILITY OF CURRENT CASH FLOWS AND ACCRUALS WITH RESPECT TO FUTURE CASH FLOWS}

\section{Panel A}

\begin{tabular}{|c|c|c|c|c|c|c|}
\hline \multirow[t]{2}{*}{ VARIABLE } & \multicolumn{3}{|c|}{$\mathrm{CF}^{*}{ }_{(\mathrm{jt+1})}$} & \multicolumn{3}{|c|}{$\mathrm{CF}_{(\mathrm{jt}+1 \text { to jt+4) }}$} \\
\hline & Coeff. & & t-Stat & Coeff. & & t-Stat \\
\hline $\mathrm{CF}$ & 0.599 & $* * *$ & 62.60 & 2.006 & $* * *$ & 42.94 \\
\hline$R \& D$ & 0.555 & $* * *$ & 34.02 & 1.721 & $* * *$ & 20.16 \\
\hline $\mathrm{ACC}$ & 0.190 & $* * *$ & 23.33 & 0.732 & $* * *$ & 21.74 \\
\hline $\mathrm{CF}^{*} \mathrm{COMP}^{\prime}$ & 0.057 & $* * *$ & 2.74 & 0.242 & $* *$ & 2.20 \\
\hline $\mathrm{R} \& \mathrm{D}^{*} \mathrm{COMP}$ & 0.126 & $* * *$ & 5.09 & 0.620 & $* * *$ & 4.72 \\
\hline $\mathrm{ACC}^{*} \mathrm{COMP}^{\prime}$ & 0.078 & $*$ & 1.95 & 0.299 & $* * *$ & 2.70 \\
\hline COMP' & -0.013 & $* * *$ & -4.68 & -0.073 & $* * *$ & -4.86 \\
\hline Constant & 0.031 & & 0.00 & 0.166 & & 0.00 \\
\hline Industry F.E. & \multicolumn{3}{|c|}{ Yes } & \multicolumn{3}{|c|}{ Yes } \\
\hline S.E. clustered by peer firm and year & \multicolumn{3}{|c|}{ Yes } & \multicolumn{3}{|c|}{ Yes } \\
\hline Observations & \multicolumn{3}{|c|}{$2,720,400$} & \multicolumn{3}{|c|}{$2,720,400$} \\
\hline R-squared & \multicolumn{3}{|c|}{0.528} & \multicolumn{3}{|c|}{0.529} \\
\hline Adjusted R-squared & \multicolumn{3}{|c|}{0.528} & \multicolumn{3}{|c|}{0.529} \\
\hline
\end{tabular}




\section{Panel B}

$$
\begin{aligned}
& C_{j t+1}^{*}\left(C_{j t+1 \text { to } t+4}^{*}\right)=\beta_{0}+\beta_{1} C_{j t}+\beta_{2} R_{j \& D_{j t}}+\beta_{3} \text { ACC }_{j t}+\beta_{4} C_{j t} * \text { COMPINNOV }_{i t}+ \\
& \beta_{5} R \& D_{j t} * \text { COMPINNOV }_{i t}+\beta_{6} \text { ACC }_{j t} * \text { COMPINNOV }_{i t}+\beta_{7} \text { COMPINNOV }_{i t}+ \\
& \text { Industry Fixed Effects }+\varepsilon_{i t}
\end{aligned}
$$

\begin{tabular}{|c|c|c|c|c|c|c|}
\hline \multirow[t]{2}{*}{ VARIABLE } & \multicolumn{3}{|c|}{$\mathrm{CF}^{*}(\mathrm{jt+1)}$} & \multicolumn{3}{|c|}{$\mathrm{CF}^{*}{ }_{(\mathrm{jt}+1}$ to jt+4) } \\
\hline & Coeff. & & t-Stat & Coeff. & & t-Stat \\
\hline $\mathrm{CF}$ & 0.609 & $* * *$ & 36.91 & 2.025 & $* * *$ & 31.22 \\
\hline$R \& D$ & 0.569 & $* * *$ & 22.24 & 1.718 & $* * *$ & 14.35 \\
\hline ACC & 0.193 & $* * *$ & 19.52 & 0.698 & $* * *$ & 14.39 \\
\hline $\mathrm{CF}^{*} \mathrm{COMPINNOV}^{\prime}$ & 0.015 & & 0.58 & 0.098 & & 0.91 \\
\hline R\&D*COMPINNOV' & 0.070 & ** & 2.57 & 0.425 & $* * *$ & 3.08 \\
\hline ACC ${ }^{*}$ COMPINNOV' & 0.015 & & 0.54 & 0.109 & & 0.97 \\
\hline COMPINNOV' & -0.009 & $* * *$ & -3.35 & -0.061 & $* * *$ & -4.48 \\
\hline Constant & 0.035 & $* * *$ & 42.33 & 0.104 & $* * *$ & 26.36 \\
\hline Industry F.E. & \multicolumn{3}{|c|}{ Yes } & \multicolumn{3}{|c|}{ Yes } \\
\hline S.E. clustered by peer firm and year & \multicolumn{3}{|c|}{ Yes } & \multicolumn{3}{|c|}{ Yes } \\
\hline Observations & \multicolumn{3}{|c|}{$2,038,812$} & \multicolumn{3}{|c|}{$2,038,812$} \\
\hline R-squared & \multicolumn{3}{|c|}{0.517} & \multicolumn{3}{|c|}{0.514} \\
\hline Adjusted R-squared & \multicolumn{3}{|c|}{0.517} & \multicolumn{3}{|c|}{0.514} \\
\hline
\end{tabular}

Table 4: Effect of accounting comparability on the predictive ability of peer firm earnings components with respect to peer firm future cash flows. Panel A shows the results when we consider all peer firms and Panel B shows the results when we consider only innovatively successful peer firms. $C F^{*}$ is the sum of cash flow from operations and $\mathrm{R} \& \mathrm{D}$ expenses, $A C C$ is earnings less cash flows from operations, $R \& D$ is $\mathrm{R} \& \mathrm{D}$ expenses, $C O M P$ is an indicator variable that takes the value of 1 for observations with accounting comparability in the top quartile of our sample and COMPINNOV' is an indicator variable that takes the value of 1 for observations with accounting comparability with innovatively successful firms in the top quartile of our sample. All other variables are defined as in Appendix 2. Standard errors are clustered by peer firm and year. *,** and $* * *$ denote significance of two tailed tests at the $10 \%$, $5 \%$ and $1 \%$ level of significance respectively. 


\section{TABLE 5}

\section{CASH FLOW FORECAST ERRORS AND INNOVATIVE EFFICIENCY}

$I E_{i t}=\beta_{0}+\beta_{1} C F_{-} F A_{i}+\beta_{2} C O M P_{i t}+\beta_{3} S_{I Z E_{i t}}+\beta_{4} M T B_{i t}+\beta_{5} L E V_{i t}+\beta_{6} C_{A P I N T_{i t}}+\beta_{7} R D S_{i t}+\beta_{8} R O A_{i t}+\beta_{9} I O_{i t}+\beta_{10} S T D A Q_{i t}+$

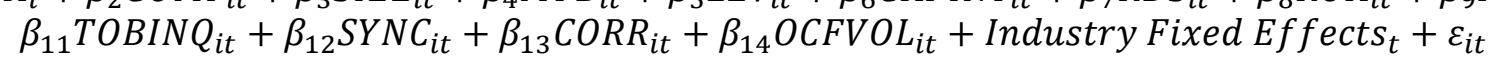

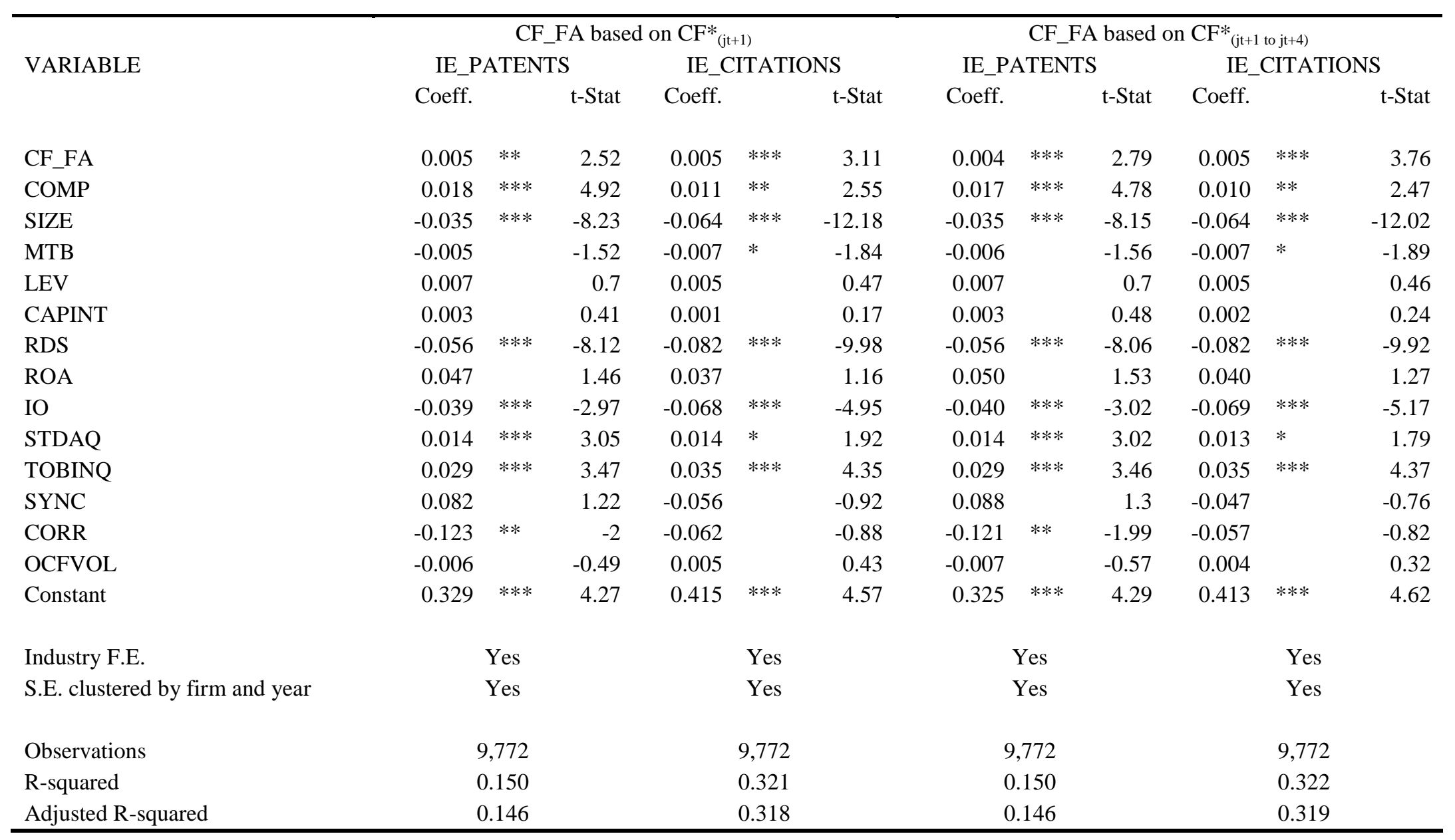


Table 5: Cash flow forecast error and innovative efficiency. $C F \_F A$ is cash flow forecast accuracy. In the first two regressions we use cash flow forecast accuracy in predicting one year ahead peer firms' cash flows where cash flow forecast accuracy is the absolute value of the median residual scaled by predicted cash flows for each subject firm from Eq. (8) when $C F_{t+l}^{*}$ is the dependent variable, multiplied by -1 so that $C F \_F A$ is more positive when the forecast accuracy is higher. In the second two equations we use cash flow forecast accuracy in predicting peer firms' aggregate cash flows, which is the absolute value of the median residual scaled by predicted cash flows for each subject firm from Eq. (8) when $C F^{*}{ }_{t+1}$ to $t+4$ is the dependent variable, multiplied by -1 so $C F \_F A$ is more positive when the forecast accuracy is higher. All other variables are defined as in Appendix 2 . Standard errors are clustered by firm and year. $*$, $* *$ and $* * *$ denote significance of two-tailed tests at the $10 \%, 5 \%$ and $1 \%$ level of significance respectively. 
TABLE 6

\section{ACCOUNTING QUALITY, FINANCIAL STATEMENT COMPARABILITY AND INNOVATIVE EFFICIENCY}

$I E_{i t}=\beta_{0}+\beta_{1}$ COMP $* S T D A Q_{i t}+\beta_{2} \operatorname{COMP}_{i t}+\beta_{3} S T D A Q_{i t}+\beta_{4} \operatorname{SIZE}_{i t}+\beta_{5} M T B_{i t}+\beta_{6} L E V_{i t}+$ $\beta_{7} C_{C A P I N T_{i t}}+\beta_{8} R D S_{i t}+\beta_{9} R O A_{i t}+\beta_{10} I O_{i t}+\beta_{11} T O B I N Q_{i t}+\beta_{12} S Y N C_{i t}+\beta_{13} C_{10 R R_{i t}}+$ $\beta_{14}$ OCFVOL $_{i t}+$ Industry Fixed Effects $t+\varepsilon_{i t}$

\begin{tabular}{|c|c|c|c|c|c|c|}
\hline \multirow[t]{2}{*}{ VARIABLE } & \multicolumn{3}{|c|}{ IE_PATENTS } & \multicolumn{3}{|c|}{ IE_CITATIONS } \\
\hline & Coeff. & & t-Stat & Coeff. & & t-Stat \\
\hline COMP *STDAQ & 0.001 & $*$ & 1.85 & 0.001 & $* *$ & 1.97 \\
\hline COMP & 0.017 & $* * *$ & 4.76 & 0.010 & ** & 2.50 \\
\hline STDAQ & 0.020 & $* * *$ & 3.61 & 0.022 & $* * *$ & 2.82 \\
\hline SIZE & -0.035 & $* * *$ & -8.19 & -0.065 & $* * *$ & -12.15 \\
\hline MTB & -0.005 & & -1.49 & -0.007 & $*$ & -1.79 \\
\hline LEV & 0.007 & & 0.73 & 0.005 & & 0.50 \\
\hline CAPINT & 0.003 & & 0.49 & 0.002 & & 0.26 \\
\hline RDS & -0.056 & $* * *$ & -8.15 & -0.082 & $* * *$ & -10.07 \\
\hline ROA & 0.045 & & 1.41 & 0.035 & & 1.09 \\
\hline IO & -0.036 & $* * *$ & -2.72 & -0.065 & $* * *$ & -4.75 \\
\hline TOBINQ & 0.029 & $* * *$ & 3.40 & 0.035 & $* * *$ & 4.24 \\
\hline SYNC & 0.078 & & 1.17 & -0.060 & & -0.99 \\
\hline CORR & -0.128 & $* *$ & -2.11 & -0.067 & & -0.94 \\
\hline OCFVOL & -0.006 & & -0.49 & 0.005 & & 0.42 \\
\hline Constant & 0.310 & $* * *$ & 4.14 & 0.394 & $* * *$ & 4.41 \\
\hline Industry F.E. & & YES & & & ES & \\
\hline S.E. clustered by firm and year & & YES & & & $\mathrm{ES}$ & \\
\hline Observations & & 9,772 & & & 772 & \\
\hline R-squared & & 0.149 & & & 32 & \\
\hline Adjusted R-squared & & 0.144 & & & 317 & \\
\hline
\end{tabular}

Table 6: Accounting quality, financial statement comparability and innovative efficiency. STDAQ is standardized accounting quality. Accounting quality, is measured as the standard deviation of residuals over the same 16 quarters used to calculate $C O M P$ obtained from the following regression model: $\triangle W C_{t}=b_{0}+b_{1} C F O_{t-1}+b_{2} C F O_{t}+$ $b_{3} \mathrm{CFO}_{t+1}+b_{4} \Delta$ Sales $_{t}+b_{5} P P E_{t}+\varepsilon_{t}$, and multiplied by minus one. COMP*STDAQ is the interaction between COMP and STDAQ. All other variables are defined as in Appendix 2. Standard errors are clustered by firm and year. $*, * *$ and $* * *$ denote significance of two-tailed tests at the $10 \%, 5 \%$ and $1 \%$ level of significance respectively. 


\section{TABLE 7}

\section{PEER TYPE, FINANCIAL STATEMENT COMPARABILITY AND INNOVATIVE EFFICIENCY}

$I E_{i t}=\beta_{0}+\beta_{1}$ COMPINNOV $_{i t}+\beta_{2}$ COMPNONINNOV $_{i t}+\beta_{3}$ SIZE $_{i t}+\beta_{4}$ MTB $_{i t}+\beta_{5}$ LEV $_{i t}+$ $\beta_{6} C_{C A P I N T}+\beta_{7} R D S_{i t}+\beta_{8} R O A_{i t}+\beta_{9} I O_{i t}+\beta_{10} S T D A Q_{i t}+\beta_{11} T O B I N Q_{i t}+\beta_{12} S Y N C_{i t}+$

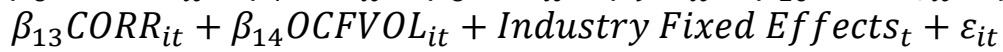

\begin{tabular}{|c|c|c|c|c|c|c|}
\hline \multirow[t]{2}{*}{ VARIABLE } & \multicolumn{3}{|c|}{ IE_PATENTS } & \multicolumn{3}{|c|}{ IE_CITATIONS } \\
\hline & Coeff. & & t-Stat & Coeff. & & $\mathrm{t}-$ Stat \\
\hline COMPINNOV & 0.022 & $* * *$ & 4.05 & 0.011 & $* *$ & 2.53 \\
\hline COMPNONINNOV & -0.008 & & -1.46 & -0.001 & & -0.46 \\
\hline SIZE & -0.034 & $* * *$ & -7.79 & -0.064 & $* * *$ & -11.68 \\
\hline МТВ & -0.005 & & -1.45 & -0.007 & * & -1.76 \\
\hline LEV & 0.002 & & 0.17 & 0.003 & & 0.31 \\
\hline CAPINT & 0.006 & & 0.82 & 0.004 & & 0.42 \\
\hline RDS & -0.059 & $* * *$ & -8.35 & -0.083 & $* * *$ & -9.87 \\
\hline ROA & 0.035 & & 1.11 & 0.028 & & 0.86 \\
\hline IO & -0.039 & $* * *$ & -2.70 & -0.059 & $* * *$ & -3.78 \\
\hline STDAQ & 0.025 & $* * *$ & 3.69 & 0.026 & $* * *$ & 2.95 \\
\hline TOBINQ & 0.029 & $* * *$ & 3.38 & 0.034 & $* * *$ & 4.04 \\
\hline SYNC & 0.075 & & 1.14 & -0.053 & & -0.85 \\
\hline CORR & -0.142 & ** & -2.39 & -0.061 & & -0.84 \\
\hline OCFVOL & -0.012 & & -0.88 & -0.001 & & -0.07 \\
\hline Constant & 0.288 & $* * *$ & 3.79 & 0.384 & $* * *$ & 4.19 \\
\hline Industry F.E. & & Yes & & & Yes & \\
\hline S.E. clustered by firm and year & & Yes & & & Yes & \\
\hline Observations & & 9,070 & & & 9,070 & \\
\hline R-squared & & 0.149 & & & 0.317 & \\
\hline Adjusted R-squared & & 0.145 & & & 0.314 & \\
\hline
\end{tabular}

Table 7: Peer type, financial statement comparability and innovative efficiency. The table shows the regression results for Eq. (7) when COMPINNOV is calculated using the Innovative Peer Sample and COMPNONINNOV is calculated using the Non-Innovative Peer Sample. All other variables are defined as in Appendix 2. Standard errors are clustered by firm and year. *, ** and *** denote significance of two-tailed tests at the $10 \%, 5 \%$ and $1 \%$ level of significance respectively. 